\title{
THE MARKET AS ALEARNING ALGORITHM: CONSEQUENCES FOR REGULATION AND ANTITRUST
}

\author{
Ramsi A. Woodcock
}

\begin{abstract}
The heart of the Chicago School's attack on the antitrust laws was a skepticism about the ability of government to improve upon unregulated market outcomes. Although the attack failed to eliminate regulation or antitrust entirely, it has proven so enduringly devastating as an intellectual matter that virtually no proposal for government regulation or increased antitrust enforcement is put forward today without an attempt either to justify the proposed departure from an assumed-legitimate free market baseline or to dismiss Chicago School skepticism as an intellectual plot bankrolled by business elites. Chicago School skepticism has been so devastating because it draws sustenance from an inapt metaphor for the economy: that of evolution through natural selection. The free market is, for the Chicago School, nature itself, and all the glories of life suggest that evolution does just fine when left to its own devices, creating a powerful basis for skepticism regarding the need for government intervention in the economy. Except that evolution never did do anything to promote economic growth, so much as theft, a fact that human beings know well given their status as predators of unparalleled success. Humanity did not escape from the subsistence economics that characterizes all of evolved life until humanity started to exert control over the forces of evolution, which is to say: to regulate.

A better metaphor for the economy than natural selection is that of a computer running a machine learning algorithm engineered to channel evolutionary forces away from theft and toward growth. The first such algorithm embraced by humanity set evolution aside almost entirely, in favor of identifying optimal productive behaviors directly. That was central planning, which flourished throughout the ancient world and was practiced globally right up to the $19^{\text {th }}$ century. The second such algorithm embraced evolution, but sought to improve upon it by imposing a rule against theft. That was the economic liberalism practiced in the West in the late $19^{\text {th }}$ century. It is also the regime favored by the Chicago School. Approached from the metaphor of the algorithm, the Chicago School's program appears retrograde, rather than foundational, because it amounts to the position that there should be no version 2.0, no further tweaks to the algorithm. But the antitrust laws, in prohibiting behavior that degrades competitors' products, even when the behavior does not amount to theft, improves upon the algorithm that is economic liberalism, better channeling life's evolutionary forces toward productivity and growth, rather than destructive forms of competition.
\end{abstract}

\footnotetext{
* Assistant Professor, University of Kentucky Rosenberg College of Law, Secondary Appointment, Department of Management, University of Kentucky Gatton College of Business \& Economics. Participants at the 2019 National Business Law Scholars Conference and a Rosenberg College of Law faculty workshop provided helpful comments. The Rosenberg College of Law generously provided summer funding.
} 


\section{Table of Contents}

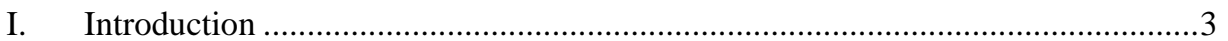

II. Airlie House.............................................................................................

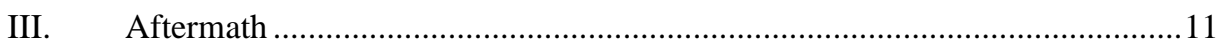

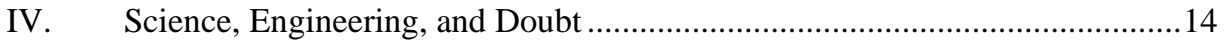

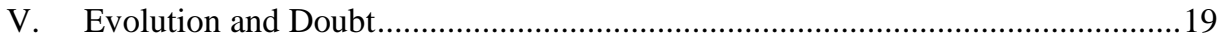

A. The Market as a Computer Algorithm ............................................................... 19

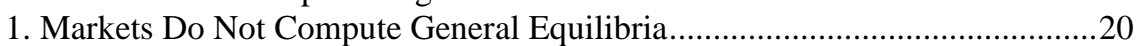

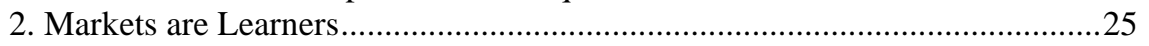

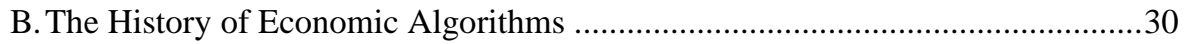

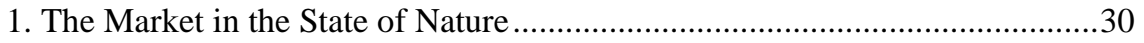

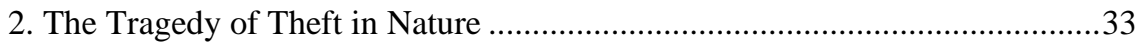

3. From Central Planning to Property Rights .............................................40

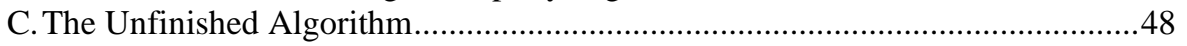

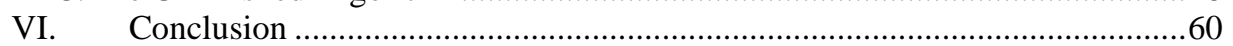




\section{INTRODUCTION}

That the heart of the Chicago revolution in antitrust was concern about error costs is by now well understood. ${ }^{1}$ In 1979, the Supreme Court adopted the antitrust meta-rule that the Court should only ever ban conduct that is known to be always or almost always harmful to consumers. ${ }^{2}$ That rule was a capitulation to the argument of Chicago School thinkers like Robert Bork that antitrust rules that incidentally condemn some good conduct could be disastrous for consumers and the economy more generally. ${ }^{3}$ Disaster could result, argued the Chicago School, because much innovative conduct looks superficially anticompetitive. ${ }^{4}$ The inventor of a revolutionary new product that consumers love often incidentally forces less-innovative firms from the market, reducing competition and driving up prices. But that effect, argued Chicago, is the virtuous result of a successful competitive process and not the sort of conduct that antitrust should condemn. ${ }^{5}$ Preventing firms from outperforming the competition would, the argument went, dissuade firms from striving to innovate. ${ }^{6}$ That would spell catastrophe for the economy because technological innovation, more than lower prices or greater output, is responsible for economic growth and indeed the bounty of the modern world. ${ }^{7}$ The stakes of antitrust error were phenomenally high, therefore, and courts would do well to let cases proceed only in those rare instances in which courts are absolutely certain that antitrust will do no harm. ${ }^{8}$

What is less well understood about the Chicago revolution in antitrust is the movement's foundation in skepticism about government regulation of all

\footnotetext{
${ }^{1}$ See Jonathan B. Baker, Taking the Error Out of Error Cost Analysis: What's Wrong with Antitrust's Right, 80 ANTITRUST L.J. 1, 2-7 (2015).

${ }^{2}$ See Broadcast Music, Inc. v. Columbia Broadcasting System, Inc., 441 U.S. 1, 8-10 (Supreme Court 1979).

${ }^{3}$ See Robert H. Bork, The Antitrust Paradox: A Policy at War with ITSElF (Free Press ; Maxwell Macmillan International 2d ed. 1993).

${ }^{4}$ See id. For an overview of Chicago School thought, see Herbert Hovenkamp, Antitrust Policy after Chicago, Mich. L. REv. 213, 226-33 (1985). For Bork's role, see George L. Priest, Bork's Strategy and the Influence of the Chicago School on Modern Antitrust Law, 57 J.L. \& ECON. S1, S1-7 (Aug. 2014).

${ }^{5}$ See BORK, supra note 3.

${ }^{6}$ See id.

${ }^{7}$ See Vincenzo Denicolò, Do Patents Over-Compensate Innovators?, 22 ECONOMIC POLICY 680, 697-99 (Oct. 2007); William D. Nordhaus, Schumpeterian Profits in the American Economy: Theory and Measurement, No. 10433, 26-27 (2004); Robert M. Solow, Technical Change and the Aggregate Production Function, 39 Rev. Econ. Stat. 312, 320 (Aug. 1957); Moses Abramovitz, Resource and Output Trends in the United States Since 1870, 46 AM. ECON. REV. 5, 13-14 (1956).

${ }^{8}$ See BORK, supra note 3.
} 
kinds, both inside and outside of antitrust. Chicago's was an entirely negative project, no different in this regard, though vastly more successful than, the movement's alter ego and occasional nemesis on the left, the critical legal studies movement. ${ }^{9}$ What Chicago did to tear down the old antitrust order was to devastate each old antitrust doctrine with skeptical arguments regarding the doctrine's economic foundations. Chicago showed, time and again, that prohibited conduct might actually be good for consumers, or society at large, and this possibility was accepted both by courts, and, perhaps more importantly, by the academic defenders of the old order itself, as sufficient to merit elimination of the doctrine. Doubt about whether antitrust was adequately distinguishing good from bad conduct proved too much for antitrust as a scientific project. As will become clear below, however, antitrust can master doubt and come back from the dead if it will only learn to understand that markets are quite literally massive machine learning computers, and the laws that regulate competition in them supply the algorithms required to ensure that markets generate optimal results. Once that is understood, skepticism about whether to have government regulation of markets makes no more sense than does skepticism regarding whether computer code is needed to ensure that a computer will run properly. Of course, you need the code. The question for policy, like the question for the programmer, is not whether to have regulation, but what regulation to have.

\section{AIRLIE House}

To appreciate how Chicago was able to wield doubt as a sword, consider, for example, the substance of the 1974 Airlie House conference on industrial concentration, which was the Waterloo of both horizontal merger policy and single firm conduct claims in antitrust. ${ }^{10}$ The salient economic fact that had driven four decades of harsh antitrust treatment for mergers and large firms was the connection between market concentration and supra-competitive profits. ${ }^{11}$ Underlying the concentration-profits relationship was the rich and nuanced theory of monopolistic competition pioneered by Edwin Chamberlin at Harvard and Joan Robinson at the University Cambridge in the 1920s and

\footnotetext{
${ }^{9}$ See Duncan Kennedy, A Critique of Adjudication: Fin de SiÈcle 359-64 (Harvard University Press 1997); Duncan Kennedy, Cost-Benefit Analysis of Entitlement Problems: A Critique, StAn. L. ReV. 387, 387-89 (1981); Richard A Posner, The Problematics of MORAL AND LEGAL THEORY 265-73 (The Belknap Press of Harvard University Press 1999). ${ }^{10}$ See generally INDUSTRIAL CONCENTRATION: THE NEW LEARNING (Harvey J. Goldschmid et al. eds., 1974) (collecting papers from the conference).

11 See Edward S. Mason, The Current Status of the Monopoly Problem in the United States, 62 HARV. L. REV. 1265, 1277-82 (1949).
} 
1930s. ${ }^{12}$ According to this theory, product differentiation alone, even with respect to so superficial a characteristic as brand name, gives firms some power over price with respect to those consumers for whom the differences matter. ${ }^{13}$ Competition between firms selling close substitutes can discipline this pricing power, but firms are forever striving to undermine this competition, either virtuously, by trying to improve their products in ways that undermine the substitutability of competing products, or unhelpfully, by trying to reduce the appeal of competing products through anticompetitive practices. ${ }^{14}$ Regardless of the means employed, some firms win out over the others, and as the number of firms in the market falls, the remaining firms recognize that they have an interest in preserving their separate and now quite large reservoirs of monopoly power. ${ }^{15}$ The firms therefore come to behave in an increasingly neighborly fashion with respect to each other, refraining from price wars or from striving too hard to improve their own products, and each seeking independently to defend the market against upstarts. ${ }^{16}$ The firms are able to earn high profits long after they have recouped any special costs they may have incurred in innovating during their competitive days, and further innovation grinds to a halt. Thus according to this theory concentration leads to a decline in competition, and that in turn to a rise in profits and a decline in innovation.

The concentration-profits connection, which had been the subject of thousands of postwar econometric studies, buttressed a postwar horizontal merger policy so harsh that Justice Stevens had declared in 1966 that the rule of decision in merger cases was that "the government always wins," and a single-firm conduct doctrine so expansive that a mere increase in production could count as illegal monopolizing behavior. ${ }^{17}$ The undesirability of market concentration was so well accepted that in 1972 Congress even entertained legislation that would have made it per se illegal simply to be one of the four largest firms in any market in which four-firm concentration ratios exceed

\footnotetext{
${ }^{12}$ See Edward Hastings Chamberlin, The TheOry of MONOPOlistic Competition: A RE-ORIENTATION OF THE THEORY OF VAlue 100-104 (Harvard Univ. Pr. 7th ed. 1956); JoAn Robinson, THE ECONOMICS OF IMPERFECT COMPETITION (Palgrave 2002); F. M. Scherer, Leonard Weiss' Contributions to Research in Industrial Organization, 10 REV. INDUS. ORG. 127, 131-32 (1995).

${ }^{13}$ See CHAMBERLIN, supra note 12, at 56.

${ }^{14}$ See id. at 113-17.

15 See id. at 46-51.

${ }^{16}$ See id.

17 See United States v. Von's Grocery Co., 384 U.S. 270, 301 (Supreme Court 1966) (Stewart, J. dissenting); United States v. Aluminum Co. of Am., 148 F. 2d 416, 430-31 (U.S. 1945). For a review of the concentration-profits studies, see Richard C. Levin \& Wesley M. Cohen, Empirical Studies of Innovation and Market Structure, in HANDBOOK OF INDUSTRIAL ORGANIZATION 1059 (Richard Schmalensee \& Robert D Willig eds., 1989).
} 
50\%. ${ }^{18}$ An influential 1989 review later concluded that the vast econometric literature supported only a weak connection between profits and concentration, but supported the existence of a connection all the same. ${ }^{19}$ At Airlie House in 1974, however, the impression of most scholars present, both the members of the postwar establishment, which was most closely associated with Harvard, and the Chicago upstarts, was that the econometric relationship was somewhat stronger. ${ }^{20}$

But that could not stop Chicago. In an article appearing after the conference, but which synthesizes the Chicago view, Sam Peltzman argued that any relation between concentration and profits need not reflect neighborly behavior by large firms to the detriment of consumers, but rather cost-saving innovation by a small firm lacking the capacity to supply the entire market. ${ }^{21}$ In this case a larger, less-cost-efficient firm might be responsible for the high concentration in the market, and the smaller, moreefficient competitor might be responsible for the high profits. The smaller competitor would earn those profits by charging a price equal to the larger firm's prices, which would be higher than the smaller firm's costs, because of the larger firm's relative inefficiency.

Needless to say, this is a very special set of facts. Peltzman made no effort to show that the markets contributing to the concentration profits connection in fact contained such low-cost competitors, although he did try, unsuccessfully, to infer their existence from data on unit costs. ${ }^{22}$ And no scholar ever went on to establish whether these facts are common or not. The reason was that for Chicago's purposes whether Peltzman's was an accurate picture of how concentrated markets actually function did not matter. What mattered was that the low-cost competitor was a plausible counterargument to the establishment wisdom that the concentration-profits relationship justified antitrust intervention. That was enough to sow the doubt that Chicago needed in order to undermine the prevailing consensus. And Peltzman's model really was brilliant at undermining the pro-enforcement implications of the concentration-profits relationship. By hypothesizing that the smaller firm's cost-saving technology could not be transferred, even in the absence of intellectual property law restrictions, and further that the

\footnotetext{
18 See Note, The Industrial Reorganization Act: An Antitrust Proposal to Restructure the American Economy, 73 ColuM. L. REV. 635, 639 (1973).

${ }^{19}$ See Levin \& Cohen, supra note 17.

${ }^{20}$ See INDUSTRIAL CONCENTRATION, supra note 10, at 162-63; HERBERT HOVENKAMP, THE ANTITRUST ENTERPRISE: PRINCIPLE AND EXECUTION 35-38 (Harvard University Press 2009) (describing the Harvard School).

${ }^{21}$ See Sam Peltzman, The Gains and Losses from Industrial Concentration, 20 J.L. \& ECON. 229, 231-32 (Oct. 1977).

${ }^{22}$ See id. at 245-52.
} 
technology might not be capable of scaling either, so that it could never be used to reduce costs market-wide, Peltzman gave a rational technological basis for the high profits earned by the smaller firm, as well as the nice aesthetic of the association of profits with smaller firms, not the large firms that antirust traditionally targeted. ${ }^{23}$ Furthermore, because the smaller firm might nevertheless compete with the larger firm for the marginal consumer, price competition might prevail and the market price might equal the average cost of the larger firm, so the market might be more or less competitive, but for the technologically-unavoidable cost advantage of the smaller firm. ${ }^{24}$ There was literally nothing antitrust could do here to improve the market. The cost-saving technology could not be spread or transferred, and breakup of the larger firm might not drive price down any further, because price might already be at the larger firm's cost. Indeed breakup might even drive cost and price up if the larger firm were already operating at minimum efficient scale given its own inferior technology. The constellation of assumptions was possible, if unlikely. But all the skeptic requires is possibility.

The postwar establishment at Airlie House was utterly helpless at fending off the skeptical mode of attack, weaned as it seems to have been on debating means to ends, rather than the worth of the ends themselves. This is painfully obvious in the dynamic between the Chicago Schoolers at Airlie House and F.M. Scherer, head of the FTC's Bureau of Economics at the time. ${ }^{25}$ Scherer was a product of the confident technocratic postwar New Deal state, the government that had asserted control over big business first to fight the Great Depression, then fascism, Nazism, Japanese imperialism, and later communism. ${ }^{26}$ This was a world in which the Ford Motor Company had shut down its consumer vehicle production lines to turn out Sherman tanks and B24 bombers during the war, a world in which national guard troops physically carried a recalcitrant Sewell Avery, head of Montgomery Ward, out of his Chicago offices and temporarily nationalized the huge retailer for refusing to pay higher wages to the workers who were clothing the troops for battle, and a world in which AT\&T fended off antitrust actions by pouring money into basic research at Bell Labs, which in 1953 invented the transistor, the key component of the microchip that made personal computers and indeed the entire information revolution of recent decades possible. ${ }^{27}$

\footnotetext{
${ }^{23}$ See id. at 231-32.

${ }^{24}$ See id. at 232-33.

${ }^{25}$ See INDUSTRIAL CONCENTRATION, supra note 10, at 460; FREDERIC M SCHERER \& MIT Press, InNOVATION AND GRowth: Schumpeterian PERSPECTIVES (London: The MIT Press 1989).

${ }^{26}$ See BARry D. KArL, The Uneasy State: The United States From 1915 To 1945 111223 (The University Of Chicago Press 1996).

${ }^{27}$ See A. J. BAIME, The ARsenal of Democracy: FDR, DETRoIT, AND AN EPIC QueSt to
} 
In a career path that sums up the action orientation of that age, Scherer started out at Harvard Business School, rather than in a department of economics, studying the drivers of innovation as part of a project funded by the military, before going into teaching and government service. ${ }^{28}$ While Scherer was a graduate student in 1959, a future advisor to President John F. Kennedy named Carl Kaysen, and a future head of the Antitrust Division of the Department of Justice and Harvard Law School lawyer-economist named Donald Turner, penned an enormously influential book calling for legislation that would prohibit concentration directly, liberating enforcers from having to find instances of bad conduct by large firms to use as excuses for bringing breakup actions under current law. ${ }^{29}$ This idea gained traction in the 1960s and Scherer arrived at Airlie House with a massive study designed to show just how far each industry in America could be deconcentrated without a loss of efficiency. ${ }^{30}$

The contrast with the Chicago spirit could not have been starker: here was economics as engineering and industrial policy at work, an economics in service of action, not doubt. In a project whose scope and ambition seems never to have been attempted before or since, Scherer quite literally worked with engineers to determine as a technological matter what the smallest efficient plant size might be in twelve major manufacturing industries, from beer to steel. ${ }^{31}$ He found that the average market share of the largest firms in eleven of the twelve industries was larger than necessary for lowest-cost

\footnotetext{
ARM AN AMERICA AT WAR 65-129 (Houghton Mifflin Harcourt Jun. 2014); Andrew Glass, FDR Seizes Control of Montgomery Ward, Dec. 27, 1944, POLITICO, https://www.politico.com/story/2016/12/this-day-in-politics-dec-27-1944-232931 (last visited Sep. 30, 2018); F.M. SCHERER, Industry Structure, STRATEGy AND PubliC POLICY 200-201 (HarperCollins College Publishers 1996) (discussing semiconductors); Roland Marchand, CReating the Corporate Soul: The Rise of Public Relations AND CORPORATE IMAGERY IN AMERICAN BIG BUSINESS (University of California Press 2001) (discussing AT\&T’s advertising).

${ }^{28}$ See SCHERER \& MIT PRESS, supra note 25.

${ }^{29}$ See CARl KAYSEN \& DONALD F TURner, ANTITRUST POLICY: An ECONOMIC AND LEGAL ANALYSIS (Harvard University Press 1959); Dennis Hevesi, Carl Kaysen, Nuclear Test Ban Negotiator (and Much More), Dies at 89, N.Y. TIMES (Feb. 19, 2010), https://www.nytimes.com/2010/02/20/us/20kaysen.html; Stephen G. Breyer, Turner, Donald F., 41 AnTITRUst BuLl. 725 (1996).

${ }^{30}$ See Herbert Hovenkamp, The Neal Report and the Crisis in Antitrust, No. ID 1348707 (Feb. 2009), https://papers.ssrn.com/abstract=1348707 (discussing a 1969 presidential report that endorsed deconcentration); FREDERIC M. SCHERER ET AL., THE ECONOMICS OF MulTIPlANT OPERATION: AN INTERNATIONAL COMPARISONS STUDY (Harvard University Press 1975); F. M Scherer, Economies of Scale and Industrial Concentration, in INDUSTRIAL CONCENTRATION: THE NeW LEARNING 16 (Harvey J. Goldschmid et al. eds., 1974).

${ }^{31}$ See Scherer, supra note 30, at 25-26.
} 
production. ${ }^{32}$ These firms could therefore safely be broken up.

Dialogue from the conference reproduced in the conference volume captures both the dismissiveness and confidence of the Chicago attacks and Scherer's poignant inability to fight back. Milton Handler, an old New Deal antitrust hand who had gone over to the defense bar, attacked Scherer's position that deconcentration would not harm efficiency in these terms: "Well, to me that is like saying that you can take a drug, a medicine, and it is not going to do you any harm. But I haven't heard him expound what good would flow from a program of deconcentration." 33 Everyone in the room was no doubt familiar with the monopolistic competition theory of concentration described above. But Scherer, as if paralyzed by the onslaught, seemed curiously unwilling to mention it, responding instead: "My role as an economist is to say 'Look, Society, if you want this kind of world, here is what it is going to cost.' But I am not willing to say, 'Do it.' I think that is the business of the legislative bodies." 34 Pressed to put up a defense, Scherer confessed to support deconcentration for "a variety of sociological and political reasons .... [B] [ I don't think it is my business to be telling society what its value judgements should be." ${ }^{35}$ It was an extraordinary non-defense coming from the then-head of an FTC Bureau of Economics, which at that very moment was in the process of developing some of the most audacious deconcentration cases ever brought, cases that by the end of the decade would go down to defeat as the Chicago School's intellectual triumph at Airlie House rippled out through the courts and enforcement agencies. ${ }^{36}$

For their part, the Chicago Schoolers had no trouble "telling society what its value judgments should be." 37 Here is an exchange at the conference between Harold Demsetz, a Chicago School economist whose intellectual role in the triumph of Chicago's antitrust agenda deserves more attention, Victor Kramer, a former white-shoe corporate lawyer who had joined the consumer movement, and Phil Neal, dean of the University of Chicago Law School, who, in a reflection of the imprecision of the "Chicago" moniker, had

\footnotetext{
32 See id. at 52.

${ }^{33}$ IndUSTRIAL CONCENTRATION, supra note 10, at 107; Sylvia Nasar, Milton Handler, 95, Is Dead; Antitrust Expert Wrote Laws, N.Y. TIMES (Nov. 12, 1998), https://www.nytimes.com/1998/11/12/business/milton-handler-95-is-dead-antitrust-expertwrote-laws.html.

${ }^{34}$ INDUSTRIAL CONCENTRATION, supra note 10, at 108.

${ }^{35} I d$.

${ }^{36}$ See F. M. Scherer, The Federal Trade Commission, Oligopoly, and Shared Monopoly, 46 REV. INDUS. ORG. 5, 15-16 (Feb. 2015) (describing this period as the genesis of cases the FTC later brought against Xerox, the eight leading oil companies, the maker of Wonder Bread, the auto industry, and the breakfast cereals industry).

${ }^{37}$ INDUSTRIAL CONCENTRATION, supra note 10, at 108.
} 
authored a 1969 report commissioned by President Johnson that called for deconcentration legislation:

Kramer: Professor Demsetz, if you were a member of the House, would you vote to repeal the Cellar Kefauver Act [which had been interpreted by the Supreme Court to protect small businesses at all costs]?

Demsetz: Yes ....

Phil Neal: Just to complete the record, I want to ask Professor Demsetz whether he would also repeal the Sherman Act.

Demsetz: The answer is, as it is currently being carried out, yes. ${ }^{38}$

Chicago's reason for this hostility was the belief that concentration was, after all, necessary for efficiency, and if Scherer's data showed that concentration was not necessary, that could only be because, as University of Virginia law professor Warren Schwartz put it, the efficiency of size had to do not with the engineering of industrial plants but the "efficiency of utilizing and generating information, the very thing you can't measure." 39 It fell to economist Leonard Weiss to remind participants that "most [theories of oligopoly] predict a positive effect of concentration on profits" in a paper that argued forcefully for the existence of an empirical relationship between concentration and profits but nevertheless managed inexplicably to conclude that the empirical support for deconcentration was inconclusive. ${ }^{40}$ Such are the wages of doubt.

The consequences of this intellectual capitulation arrived swiftly.

${ }^{38}$ Id. at 235; Joe Holley, Victor H. Kramer; Founded Center for Law, Social Policy, (Jan. 13, 2007), http://www.washingtonpost.com/wpdyn/content/article/2007/01/12/AR2007011202109.html; Phil C. Neal, Former Law School Dean, 1919-2016, UNIVERSITY OF CHICAGO NEWs, https://news.uchicago.edu/story/phil-cneal-former-law-school-dean-1919-2016 (last visited Sep. 30, 2018); Hovenkamp, supra note 30 , at 2-5. For the Demsetz contribution that laid the foundation for the Chicago triumph, see Harold Demsetz, Industry Structure, Market Rivalry, and Public Policy, 16 J.L. \& ECON. 1, 1-3 (Apr. 1973)..

${ }^{39}$ INDUSTRIAL CONCENTRATION, supra note 10, at 107.

${ }^{40}$ Leonard W. Weiss, The Concentration-Profits Relationship and Antitrust, in INDUSTRIAL CONCENTRATION: THE NEW LEARNING 184, 192 (Harvey J. Goldschmid et al. eds., 1974). For the strangeness of Weiss's conclusions, see INDUSTRIAL CONCENTRATION, supra note 10 , at 240 . 
Legislative deconcentration disappeared from the policy agenda virtually overnight and within a decade major FTC cases targeting concentrated industries had all gone down to defeat under the extraordinary threat of Congress in some instances to defund the Commission if the cases were to continue. ${ }^{41}$ The lower courts started turning back merger challenges, merger enforcement entered a decades-long winter form which it has still not emerged, and over time almost every area of antitrust enforcement went into decline, with the exception of cartel enforcement. ${ }^{42}$

\section{AFTERMATH}

In the decades after Airlie House, Chicago School skepticism regarding antitrust or government intervention in markets more generally has come to rest upon a more elegant and simple counterexample than Peltzman's pygmy cost reducer. The Chicago School now argues that neither accountants nor economists are any good at measuring costs, particularly the risk-adjusted costs of research and development, and as a result any large firm, and any apparent pot of monopoly profits, may well be essential to the production of the innovative products that distinguish the modern economy from the subsistence economies of all preceding ages of human history. In its crassest form, however, the innovation argument was that increasing the profits of the firm, whether by fielding better products, or shooting a competitor's top managers in the face, could eventually improve, or further improve, the quality of a firm's products, because the firm might reinvest some of the increased profits in research and development, which might in turn lead to better products. ${ }^{43}$ To date, Chicago has advanced this form of the argument most unabashedly in defense of reverse payment patent settlements, which are agreements between branded and generic drug makers for generic drug makers to stay out of drug markets in exchange for a share of the profits generated by the resulting reduction in competition. ${ }^{44}$ Even though those

\footnotetext{
${ }^{41}$ See Scherer, supra note 36, at 20-21; William E. Kovacic, Failed Expectations: The Troubled Past and Uncertain Future of the Sherman Act as a Tool for Deconcentration, 74 IOWA L. REV. 1105, 1106-9, 1119 (1989).

42 See Andrew I Gavil et al., ANTitrust Law in Perspective: Cases, Concepts, AND PROBlems IN COMPETITION POLICY 697-700 (3d ed. 2017); JoHN E KWOKA, MERGERS, Merger Control, AND Remedies: A Retrospective ANAlysis of U.S. Policy (2015); Ramsi A. Woodcock, Per Se in Itself: How Bans Reduce Error in Antitrust (2016) (summarizing the changes in antitrust law).

${ }^{43}$ See Verizon Commc'ns Inc. v. Law Offices of Curtis V. Trinko, 540 U.S. 398, $406-7$ (U.S. 2004).

${ }^{44}$ See generally C. Scott Hemphill, Paying for Delay: Pharmaceutical Patent Settlement as a Regulatory Design Problem, 81 N.Y.U. L. REV. 1553, 1557-59 (2006) (discussing these settlements).
} 
profits have been generated through a scheme of naked market allocation, normally one of the gravest of antitrust offenses, Chicago apologists argued, and for a decade the courts agreed, that they should be allowed because they would enable branded drug companies to invest in better drugs. ${ }^{45}$

The argument that profits, however acquired, lead to innovation has come to be known as the "dynamic efficiency" argument, and it cast doubt on the entire antitrust enterprise by suggesting that monopoly profits might be good in themselves. ${ }^{46}$ Here again what mattered was not building a scientific consensus around the new theory, which would have made the theory a constructive project, but instead merely establishing the theory as a sufficiently plausible alternative to the prevailing consensus to justify dissent. It did not matter that Kenneth Arrow, the perfecter of mathematical general equilibrium theory, had famously hypothesized that competition leads to more investment in innovation than does monopoly because firms operating in a competitive market have more to gain from success than does a monopolist, which already dominates the market. ${ }^{47}$ Nor did it matter that monopolies stand to gain from selling innovative products only to the extent that the new products compete with products sold in other non-monopolized markets, which is to say, only to the extent that competition in fact continues to exist on the margins of the monopolized market. ${ }^{48}$ Nor did it matter that no link between monopoly and innovation had ever been established as an empirical matter. ${ }^{49}$ All Chicago needed was doubt.

This skeptical mode reached its highest expression in a reinterpretation of error cost arguments initially made by Frank Easterbrook. ${ }^{50} \mathrm{He}$ argued in the early 1980s that the risk of harm to victorious firms posed by antitrust enforcement is particularly large, because once antitrust enforcers mistakenly break up a good firm, the firm is gone forever. ${ }^{51}$ Indeed, entrepreneurs

\footnotetext{
45 See Fed. Trade Comm'n v. Actavis, Inc., 133 S.Ct. 2223, 2235-38 (2013), Valley Drug Co. v. Geneva Pharm., Inc., 344 F. 3d 1294, 1308 (court.appeals 2003); United States v. Topco Associates, Inc., 405 U.S. 596, 611-13 (Supreme Court 1972); Robert D. Willig \& John P. Bigelow, Antitrust Policy Toward Agreements That Settle Patent Litigation, 49 ANTITRUST BULL. 655 (2004).

46 See J. Gregory Sidak \& David J. Teece, Dynamic Competition in Antitrust Law, 5 J. COMPETITION L. \& ECON. 581 (2009).

${ }^{47}$ See Kenneth Arrow, Economic Welfare and the Allocation of Resources for Invention, in THE RATE AND DIRECTION OF INVENTIVE ACTIVITY: ECONOMIC AND SOCIAL FACTORS 609 (R. Nelson ed., Princeton University Press 1962).

${ }^{48}$ See Ramsi A. Woodcock, The Antitrust Duty to Charge Low Prices, 39 Cardozo L. REV. 1741 (2018).

49 See F. M Scherer \& DAvid Ross, Industrial Market Structure AND ECONOMiC PERFORMANCE 640-60 (3d ed. 1990).

${ }^{50}$ See Frank H. Easterbrook, The Limits of Antitrust, 63 TEX. L. REV. 1, 14-17 (1984).

${ }^{51}$ See id. at 2-3 ("If the court errs by condemning a beneficial practice, the benefits may be
} 
anticipating mistaken antitrust interference will not even bother to enter markets at all, leading to permanent economic harm. ${ }^{52}$ By contrast, argued Easterbrook, if antitrust enforcers fail to condemn a firm that is genuinely engaged in anticompetitive conduct, the harm is not permanent, because the monopoly profits generated by the firm will attract competition, and eventually the firm's monopoly power will erode.$^{53}$ The relevant permanence of harm inflicted by too aggressive, as opposed to too gentle, antitrust enforcement, argued Easterbrook, counsels in favor of gentle enforcement, or no enforcement at all. ${ }^{54}$ This argument merged with the innovation-based skepticism that flowered first in the 1990s. ${ }^{55}$ Innovation, argued Easterbrook acolytes, necessarily harms competitors that fail to innovate, and that harm to competition creates a risk that enforcers will mistake innovative firms for firms engaged in anticompetitive conduct. ${ }^{56}$ Add to that the fact that economists agree that innovation is the principal driver of economic growth, and both the probability that antitrust enforcers will make mistakes and the harm caused by those mistakes appear large, making antitrust enforcement a very dangerous proposition indeed. ${ }^{57}$

None of these arguments were constructive. Chicago did not seek to build a consensus in favor of these positions by refuting counterarguments. The movement did not seek to explain, for example, why a firm that had been broken up mistakenly might not knit itself back together rather quickly, particularly if the original firm really had been innovative and beloved of consumers and size really had been key to its success. Indeed, the story of antitrust breakups has been one of reknitting. Targets from Standard Oil to AT\&T have reconstituted themselves in dramatic fashion. ${ }^{58}$ And the more

lost for good. ... If the court errs by permitting a deleterious practice, though, the welfare loss decreases over time.").

${ }^{52}$ See id.

${ }^{53}$ See id.

${ }^{54} \mathrm{See}$ id. at 39-40 (stating that "bias in favor of business practices is appropriate").

${ }^{55}$ For a critical discussion of 1990s-era innovation-based skepticism, see See Richard M. Brunell, Appropriability in Antitrust: How Much Is Enough?, 69 ANTITRUST L.J. 1, 1-4 (2001).

${ }^{56}$ See Geoffrey A. Manne \& Joshua D. Wright, Innovation and the Limits of Antitrust, 6 J. COMPETITION L. \& ECON. 153, 167 (2010).

${ }^{57}$ See id. For the economic consensus that innovation drives growth, see Kenneth J. Arrow, Workshop on the Economy as an Evolving Complex System: Summary, in THE ECONOMY AS AN EVOLVING Complex System 275, 281 (Philip W. Anderson et al. eds., Addison-Wesley 1988) ("Innovations . . . are one of the least analyzed parts of economics, in spite of the verifiable fact that they have contributed more to per capita economic growth than any other factor.").

58 See Chart: The Evolution of Standard Oil, VISUAL CAPITALisT, http://www.visualcapitalist.com/chart-evolution-standard-oil/ (last visited Aug. 9, 2018);

Nilay Patel, Look at this Goddamn Chart, THE VERGE, 
innovative the technology, the quicker one might expect the market to race back to minimum efficient scale, because the more innovative the technology the more consumers are willing to pay for it, and the greater the profits to be earned from producing the technology most efficiently. The Chicago School did not need to address these counter-arguments because the Chicago School's own account was at least plausible, and that was all the Chicago School needed to sow doubt.

\section{SCIENCE, ENGINEERING, AND DOUBT}

The reason that the pre-Chicago-revolution establishment at Airlie House comes across as a paralyzed deer in headlights is that science has in fact no antidote for doubt: not even in the realm of mathematics does science push forward by proving away doubt. Instead, science requires consensus, and consensus in turn is a subjective and social thing: it depends on who happens to belong to the community of scientists and what they happen to want from science. ${ }^{59}$ An intelligent and motivated skeptic can refuse to accept any scientific theory without sacrificing a commitment to reasoned argumentation. ${ }^{60}$ What Scherer and the rest of the establishment faced was a collapse of consensus regarding the core facts of antitrust economics. The notion that concentration allows firms to generate inefficiently large profits had been the foundation of postwar antitrust: the basis for a vigorous merger policy designed to prevent markets from self-concentrating, as well as for a vigorous antimonopolization policy designed to ensure that markets that become concentrated do not stay concentrated. ${ }^{61}$ The fact that, like the notion that demand curves are downward sloping, or that cartels drive up prices, the concentration-profits relationship had proven somewhat difficult to pin down in the data, had never been taken to undermine a relationship that appeared too common-sensical to doubt. ${ }^{62}$ The fault, it had always been assumed, lay

\footnotetext{
https://www.theverge.com/2016/10/24/13389592/att-time-warner-merger-breakup-bellsystem-chart (last visited Sep. 13, 2019).

59 See Thomas S. Kuhn, The Structure of ScIEnTIFIC Revolutions 15 (University of Chicago Press 1970).

${ }^{60}$ See Pedro Domingos, The Master Algorithm: How the Quest for the Ultimate LEARNING MACHINE WILl REMAKE OUR WORLD 58-65 (2018) (discussing Humian doubt).

${ }^{1}$ See Herbert Hovenkamp, United States Competition Policy in Crisis: 1890-1955, 94 MinN. L. REV. 311, 359 (2009).

62 See Michael D Whinston, Lectures on Antitrust ECONOMiCs 26-27 (2008) (observing that the "published literature [on price fixing] offers less evidence [regarding the effects of cartels on prices] than one might expect"); Valdimar Sigurdsson et al., The Behavioural Economics of Neutral and Upward Sloping Demand Curves in Retailing, 31 THE SERVICE INDUSTRIES JOURNAL 2543 (Nov. 2011).
} 
in the inability of empirical methods to isolate the relationship in noisy data. ${ }^{63}$ Indeed, Scherer claimed precisely that at Airlie House, observing that there was strong evidence that concentration leads to higher costs, suggesting that firms squander the higher profits they derive from concentration, obscuring the concentration-profits relationship in the data. ${ }^{64}$ But in the Chicago School this view finally encountered a group of highly-credentialed experts - a part of the scientific community-who insisted upon doubting.

Rene Descartes famously laid the foundation both for the scientific method and modern philosophy when he insisted that all knowledge be tested by doubt. ${ }^{65}$ That worked well enough in science because as a purely sociological matter scientists proved willing to be convinced to suspend disbelief once some level of empirical and theoretical support for a given proposition had been reached ${ }^{66}$ But for philosophers, whose business it is to follow ideas to their logical extremes, doubt proved a death sentence. The problem of solipsism - the inability to refute skepticism regarding even the true existence of the world as it is exposed to our senses - has bedeviled philosophers ever since Descartes, and made them unable to contribute further to great debates regarding virtue, the nature of art, and many other matters in which philosophy once played a leading role ${ }^{67}$ If you cannot be sure the world even exists, there is precious little you can say about life in that world. Doubt can trip up even so self-confident a discipline as mathematics. The only reason that mathematicians can say for sure that the square of the hypotenuse is always the sum of squares of a right triangle's legs is that mathematicians as a group agree that the proof works. ${ }^{68}$ If an eminent mathematician were to dissent, there would be trouble. Fortunately, none have.

The Chicago attack on scientific consensus in antitrust was part of a broader attack by the Chicago School on all of the learning that justified government intervention in markets. In macroeconomics, Milton Friedman sowed doubt about the connection between government spending and economic growth that served as the foundation for the interventionist Keynesian School. ${ }^{69}$ In the field of economic regulation, the public choice

\footnotetext{
${ }^{63}$ See IndUSTRIAL CONCENTRATION, supra note 10, at 163.

${ }^{64}$ See id. at 239.

${ }^{65}$ See John Gribbin, THE SCIENTISTS: A History OF SCIENCE TOLD through THE LiVES OF ITS GREATEST INVENTORS 114-15 (Random House 2008).

${ }^{66}$ See KuHN, supra note 59.

${ }^{67}$ Probably the greatest, if failed, attempt to reconstruct philosophy after Descartes was that of Immanuel Kant. See IMMANUEl Kant, CRITIQUE OF PURE REASON (Paul Guyer \& Allen W. Wood trans., Cambridge University Press 1998).

${ }^{68}$ See What is Mathematical Truth?, 2 Historia MAthematiCA 529, 529 (Nov. 1975).

${ }^{69}$ See Robert E. Hall \& Thomas J. Sargent, Short-Run and Long-Run Effects of Milton
} 
movement sowed doubt about the notion that administrative agencies could be relied upon to carry out their missions, rather than to maximize their own wealth and power. ${ }^{70}$ The most general attack on lawmaking itself came from Ronald Coase, and deserves a closer look. Coase's contribution is often mistakenly thought to be the so-called Coase Theorem, the observation that when bargaining is costless, injurer and victim will bargain to an efficient solution of their conflict, regardless whether the law prohibits injury or not. ${ }^{71}$ If, for example, the injury is efficient, the injurer will be willing to pay damages when injury is prohibited, and will of course simply act without needing to worry about legal consequences if injury is not prohibited. ${ }^{72}$ So either way the action will take place. ${ }^{73}$ The real thesis of Coase's famous article, The Problem of Social Cost, was, however, that in the real world bargaining is not costless, and so it is impossible to say for sure whether the parties will bargain to the efficient solution or not. ${ }^{74}$ The law, argued Coase, might try to respond to the possible failure of bargaining by eliminating liability, in order to ensure that the injurer has the freedom to injure, avoiding the need for the injurer to reach a deal with the victim prior to acting. ${ }^{75}$ But whether that is efficient depends on whether injury really is efficient. ${ }^{76}$ Courts rarely know whether injury really is efficient in any given case, and if injury is not efficient, but bargaining impossible in a world of high transaction costs, then the absence of liability would allow injury to take place when injury should not. ${ }^{77}$ Coase concludes that judges simply lack the information to choose rules in a way that they can be certain will be good for society. ${ }^{78}$ Coase's real project was to sow doubt about the ability of the law to solve real world problems, not to show that the world is naturally efficient. Like other Chicago School projects, Coase's was not constructive, but destructive. The willingness of lawyers to seize on the Coase Theorem - a constructive, if hopelessly idealized, project - as Coase's contribution shows how little lawyers understood the Chicago School's strategy. ${ }^{79}$

Friedman's Presidential Address, 32 The Journal of ECONOMIC PerSPeCtIVES 121, 122 23 (2018).

${ }^{70}$ See George J. Stigler, The Theory of Economic Regulation, 2 THE BeLl JouRnal of ECONOMICS AND MANAGEMENT SCIENCE 3, 3 (1971).

${ }^{71}$ See Robert CoOter \& ThOMAS Ulen, LAW \& ECONOMics (Prentice Hall 6th ed. 2012).

${ }^{72}$ See id.

${ }^{73}$ See id.

${ }^{74}$ See R. H. Coase, The Problem of Social Cost, 3 J.L. \& Econ. 1, 15-19 (Oct. 1960).

${ }^{75}$ See id.

${ }^{76}$ See id.

${ }^{77}$ See id.

${ }^{78}$ See id. at 44.

${ }^{79}$ See Robert C. Ellickson, Of Coase and Cattle: Dispute Resolution among Neighbors in Shasta County, StAn. L. Rev. 623 (1986). 
Regulation stands no chance under the scientific model because regulation has immediate real world stakes, creating winners and losers, and the losers may always deploy skepticism to undermine any consensus. Perhaps for this reason, advocates of the regulatory state have long appealed to a different paradigm for regulation: that of engineering. ${ }^{80}$ Contrary to popular fantasies about the theoretical tidiness of modern engineering, engineering has always been, and remains, a field that advances through trial and error, which is to say, a field that privileges action over doubt. ${ }^{81}$ The days are gone when mechanical engineers simply rebuilt cathedrals and bridges until they stopped falling down, ignorant of the basic Newtonian rules of static equilibrium. ${ }^{82}$ But perusal of any engineering text reveals how little engineers still know about how, for example, cracks form and propagate through materials. ${ }^{83}$ Aeronautics, probably the subfield that epitomizes the triumph of modern engineering, might seem to the outside observer to rest on firm theoretical foundations, with the forces governing air flow around planes, and the lift that keeps them airborne, reduced to mathematical equations that can be applied to determine the effectiveness of any new airplane design. The truth, however, is that while there are differential equations that describe air flow, there is no known solution to those equations, with the result that engineers cannot predict with certainty whether a new design will fly. ${ }^{84}$ If the Chicago School, with its aversion to any risk of error, were running the aeronautical engineering profession, no planes would be built, because the error costs of getting a design wrong far exceed those of any antitrust trial, at least if the loss of life is not reduced to financial terms - another Chicago School initiative. ${ }^{85}$

But fortunately, the absence of certainty has not induced aeronautical engineers to keep planes out of the air. To this day, engineers rely on no more than trial and error as a basis for action. They blow wind at model planes in a wind tunnel or in a computer simulation and then hope that the real thing will behave in the same way as does the model. ${ }^{86}$ When engineers are proven

${ }^{80}$ See Roscoe Pound, The Lawyer as a Social Engineer Law and Medicine-A Symposium, 3 J. PUB. L. 292 (1954).

${ }^{81}$ See J. E Gordon, StruCtures: OR Why Things DON'T FALl DOWn (2013).

${ }^{82}$ See id.

${ }^{83}$ See id.

${ }^{84}$ See, e.g., Alexandre Joel Chorin, Numerical Solution of the Navier-Stokes Equations, 22 MATHEMATICS OF COMPUTATION 745 (1968).

${ }^{85}$ See W. Kip Viscusi \& Joseph E. Aldy, The Value of a Statistical Life: A Critical Review of Market Estimates Throughout the World, 27 JOURNAL OF RISK \& UNCERTAINTY 5 (Aug. 2003).

${ }^{86}$ See Philosophies and Fallacies in Turbulence Modeling, 74 PROGRESS IN AEROSPACE SCIENCES 1 (Apr. 2015). 
wrong by experience, they revise their designs and try again. For aeronautical engineers, airplane passengers always have and will be guinea pigs, whether they live or die always providing engineers with more information about how to improve their designs. The high death rates in the early days of flight, and the decline since, testifies to the audacity and success of the engineer's strategy of trial and error. ${ }^{87}$ For advocates of regulation, who for a century now have spoken of regulation as "social engineering," regulation must be understood to advance by the same process of trial and error, a process that cannot exist if the criterion for action is the elimination of doubt. ${ }^{88}$ To fly, it is necessary to act, and to continue to act even in the face of failure. It is possibility of progress, and not the elimination of doubt, that should justify further action.

This heroic vision of engineering has, over just about the same period during which Chicago has triumphed in antitrust, come under a skeptical assault of its own, in the form of the environmental movement and, more broadly, a critique based on the economic concept of externalities. ${ }^{89}$ According to this critique, the successes of trial and error, all the engineering marvels of the modern age, are illusions generated by an excessively narrow focus. ${ }^{90}$ Zoom out, and it becomes clear that no progress has been made, and indeed the world may well be much worse off. ${ }^{91}$ Climate change, for example, calls into question almost all modern engineering achievements, powered as they have been by hydrocarbons. ${ }^{92}$ The spirit of this engineering skepticism is perhaps best captured by Jared Diamond's memorable 1987 article in Discover, in which Diamond argued that agriculture-the engineering achievement that made history itself possible - may well have been a terrible mistake for humanity, opening the species up to disease, social inequality, and much else. ${ }^{93}$ Trial and error may have been disastrous after all.

Despite Chicago's famous hostility toward environmentalism, Chicago critiques of antitrust very much register in an environmentalist key, only the

87 See Fatal-Accidents-Per-Year-1946-2017.Jpg (JPEG Image, $1300 \times 650$ Pixels), https://aviation-safety.net/graphics/infographics/Fatal-Accidents-Per-Year-1946-2017.jpg (last visited Sep. 30, 2018).

${ }^{88} \mathrm{See}$ Morton J. HoRwitz, THE TRANSFORMation OF AMERICAN LAW, 1780-1860 (1977).

${ }^{89}$ See William J. Baumol, On Taxation and the Control of Externalities, 62 Am. ECon. ReV. 307 (Jun. 1972).

${ }^{90}$ See id.

${ }^{91}$ See id.

92 See William D. Nordhaus, Managing the Global Commons: The Economics of Climate Change (MIT Press 1994).

${ }_{93}$ See Jared Diamond, The Worst Mistake in the History of the Human Race, DISCOVER (1987), http://discovermagazine.com/1987/may/02-the-worst-mistake-in-the-history-of-thehuman-race. 
pollution that concerns Chicago is regulatory influence on markets that harms consumers. $^{94}$ The establishment that Chicago attacked cared about consumers, but the welfare of consumers had never been the establishment's primary goal. Instead, that goal, the end of antitrust as social engineering, was always competition above all else. ${ }^{95}$ Interestingly, Chicago never questioned the ability of antitrust's engineers to achieve greater competition. Chicago never questioned whether, in a world of deconcentrated markets, there would in fact be more competition. Chicago's environmentalist turn was to argue instead that deconcentration and other antitrust strategies designed to keep business small and markets competitive had the bad externality of impoverishing consumers, by depriving consumers of the innovative products that only big firms can churn out. ${ }^{96}$ This was the origin of Chicago's most important doctrinal contribution to antitrust: the consumer welfare standard, which prohibits antitrust enforcers today from challenging anticompetitive behavior if that behavior in fact makes consumers better off. ${ }^{97}$ In focusing on consumer welfare, Chicago's goal was to charge that the externalities created by antitrust in promoting competition render the entire antitrust enterprise no longer worthwhile. ${ }^{98}$ Antitrust may be able to get the competitive propeller spinning, and the competitive market off the ground, but if the consumer environment is harmed as a result, then the social engineering project is a failure.

\section{EvOlution AND DoubT}

\section{A. The Market as a Computer Algorithm}

What the pre-Chicago antitrust establishment lacked in defending antitrust against Chicago School skepticism was the right metaphor. Antitrust, and government regulation more generally, are not scientific

\footnotetext{
${ }^{94}$ For Chicago's hostility to environmentalism, see the critique of Arthur Pigou's call to ban pollution in Coase, supra note 74, at 39-41.

95 See, e.g., Brown Shoe Co. v. United States, 370 U.S. 294, 344 (Supreme Court 1962) ("[W] cannot fail to recognize Congress" desire to promote competition through the protection of viable, small, locally owned businesses. Congress appreciated that occasional higher costs and prices might result from the maintenance of fragmented industries and markets. It resolved these competing considerations in favor of decentralization. We must give effect to that decision.").

96 See Demsetz, supra note 38, at 2.

${ }^{97}$ See Steven C. Salop, Question: What Is the Real and Proper Antitrust Welfare Standard? Answer: The True Consumer Welfare Standard, 22 LOY. CONSUMER L. REV. 336 (2010); John B. Kirkwood \& Robert H. Lande, The Fundamental Goal of Antitrust: Protecting Consumers, Not Increasing Efficiency, 84 NOTRE DAME L. REV. 191 (2008).

${ }^{98}$ See Easterbrook, supra note 50; Manne \& Wright, supra note 56.
} 
projects, properly pursued only when the consequences have been proven to the satisfaction of all experts. But antitrust is also not an engineering project in the mode of the airplane, or industrialization more generally, capable of achieving liftoff and economic growth, but also of inflicting offsetting externalities. Regulation is instead the code that governs the machine learning algorithm that is the market. ${ }^{99}$ As such, the question whether to have regulation makes no more sense than the question whether to have an economy. Regulation is there whether we like it or not. The only question is what the content of the algorithm that drives the market computer should be.

\section{Markets Do Not Compute General Equilibria}

The notion that markets are computers is not new. But there has long been a misunderstanding regarding the nature of the computers' programming. Perhaps the most common-and mistaken-view is that markets are computers that accurately solve a massive optimization problem regarding the production and allocation of resources. ${ }^{100}$ The idea here is that economic management is the problem of how to ensure that people produce the things that people most want to consume, and economic agents protected by property rights, motivated by the pursuit of private profits, and free to transact with each other, solve that problem to perfection, as if there were an invisible hand allocating resources always to their most productive uses. ${ }^{101}$

For about a century, starting with the work of León Walras in the 1870s, economists built up a massive mathematical model that showed that profitdriven economic agents subject to limits imposed by property law will engage in transactions that allocate resources to those who value them the most. ${ }^{102}$ An important condition, however, was that price in every market be set to ensure that every buyer who places a value on a good that exceeds its cost of production be able to afford the good, a condition often summarized as being that "price equilibrate supply and demand" in every market or, on

\footnotetext{
${ }^{99}$ See DOMINGOS, supra note 60, at 6.

100 See HAL R VARIAN, InTERMEDIATE MiCROECONOMICS: A MODERN APPROACH 585 (7th ed. 2006) ("The importance of the First Welfare Theorem [which gives the conditions under which efficiency is achieved in the general equilibrium model] is that it gives a general mechanism - the competitive market [assumed to drive prices to equilibrate supply and demand] — that we can use to ensure Pareto efficient outcomes.") (emphasis added).

101 See Andreu Mas-Colell et Al., Microeconomic TheOry 546-50 (Oxford U.P. 1995); AdAM SMITH, THE WEALTH OF NATIONS 572 (Bantam Classic) (first using the phrase "invisible hand" to describe the behavior of the economy).

102 See MARK BLAUG, ECONOMIC THEORY IN RETROSPECT 570-74 (4th ed. 1985) (discussing Walras's contribution); E. Roy Weintraub, Appraising General Equilibrium Analysis, 1 ECONOMICS AND PHILOSOPHY 23, 30-33 (Apr. 1985) (outlining the intellectual history of general equilibrium from the 1930 s onward).
} 
the assumption that perfect competition equilibrates supply and demand, that prices be "competitive." 103 Price needed to equilibrate supply and demand for markets to operate efficiently because whenever a buyer places a higher value on a good than its cost - which measures the value that the seller places on the good-price must ensure that the good changes hands in order for markets to cause goods to flow to their highest-valued uses. ${ }^{104}$

Economists spent the ensuing century proving important things about this model, including that a set of supply- and demand-equilibrating efficient prices can exist in all markets at the same time. ${ }^{105}$ But one thing economists discovered that they could not prove was that markets will always actually find those prices. ${ }^{106}$ Walras assumed that bidding of the sort he encountered in $19^{\text {th }}$ century stock markets would drive prices to equilibrium in each individual market. ${ }^{107}$ In the markets that Walras had in his mind's eye, an auctioneer calls out a price and traders signal how many shares they are willing to buy or sell at the quoted price. ${ }^{108}$ If there is excess demand-more shares ordered than offered - the auctioneer cancels the transaction and calls out a higher price. ${ }^{109}$ If there is excess supply, the auctioneer calls out a lower price. ${ }^{110}$ This continues until the auctioneer quotes a price at which supply equals demand, which must be the price at which all buyers willing to pay the cost of production for their units are able to buy. ${ }^{111}$

Free market economists loved Walras's story because it suggested that markets convert a virtually intractable mathematical problem into a tractable one. ${ }^{112}$ The mathematical model of general equilibrium is a set of equations, one for each economic agent, that determines the set of resources that maximize the agent's profits subject to the argent's budget and prevailing

${ }^{103}$ See VARIAN, supra note 100, at 307-8, 577 (using the two phrases interchangeably and relating them to the price at which all those who are willing to pay the costs of production are able to purchase goods).

${ }^{104}$ See id. at 307-8.

105 See BlaUg, supra note 102, at 574-77; Weintraub, supra note 102, at 30-33; Frank Ackerman, Still Dead after All These Years: Interpreting the Failure of General Equilibrium Theory, 9 Journal of ECONOMIC Methodology 119, 121 (Taylor \& Francis Journals 2001).

${ }^{106}$ See Ackerman, supra note 105, at 121-23.

107 See Donald A. Walker, Walras's Theories of Tatonnement, 95 JOURNAL OF POLITICAL ECONOMY 758, 760 (University of Chicago Press 1987).

${ }^{108}$ See id. at 760-62.

${ }^{109}$ See id.

${ }^{110}$ See id.

111 See id.; VARIAN, supra note 100, at 307-8. For a formal definition of this process of "Walrasian tâtonnement," see See MAS-COLELL ET AL., supra note 101, at 620-21.

112 See VARIAN, supra note 100, at 585-86. 
market prices. ${ }^{113}$ Reconciling all of these equations gives the optimal allocation of resources. ${ }^{114}$ But in an economy with millions of people and products, no computer, existing or remotely feasible of future construction can solve the problem in a realistic amount of time. ${ }^{115}$ That suggested to the Chicago School that central planners could never hope to operate the economy efficiently by fiat. ${ }^{116}$

By contrast, markets could solve the allocation problem. All economic agents had to do was know their own preferences and strive to satisfy them in light of prices quoted by auctioneers and economic agents' purchase decisions would then magically add up in aggregate to an economy-wide efficient allocation of resources. ${ }^{117}$ But then who or what solved the allocation problem in the market context, if not a central planner's computer? It could not of course be an actual invisible hand. The answer was: the market economy itself, understood as a vast performative computation machine, in which individual economic agents, acting as computational nodes solving the mathematically tractable problem of how to maximize their own private profits, ended up working in tandem to solve the market problem as a whole. ${ }^{118}$ It was society as a massive parallel computing farm.

The fatal flaw in this account was not that Walrasian auctions are hard to find in actual markets. That problem could be surmounted by forcing transactions into auction-style markets, something that the law had long tried to do going all the way back to the prohibition on forestalling in the premodern period. ${ }^{119}$ The really insurmountable flaw was that even if markets were all Walrasian auctions, they would not lead to efficient prices,

\footnotetext{
113 See MAS-COLELL ET AL., supra note 101, at 546-48. I mean "profit" here in a broad sense to include the happiness of individuals, and not just the excess of revenues over costs of business firms.

114 See id.

115 See Cosma Shalizi, In Soviet Union, Optimization Problem Solves You, CROOKED TIMBER, http://crookedtimber.org/2012/05/30/in-soviet-union-optimization-problemsolves-you/ (last visited Jan. 24, 2019).

116 See F. A. HAYeK, The FATAl CONCEIT: THE ERrors of Socialism 86 (University of Chicago Press Jul. 2011); VARIAN, supra note 100, at 585-86.

117 See HAYEK, supra note 116, at 86-87; VARIAN, supra note 100, at 585-86 ("The only things that a consumer needs to know to make his consumption decisions are the prices of the goods he is considering consuming. . . . If each consumer knows only the prices of the goods, he can determine his demands, and if the market functions well enough to determine the competitive prices, we are guaranteed an efficient outcome. The fact that competitive markets economize on information in this way is a strong argument in favor of their use as a way to allocate resources.").

${ }^{118} \mathrm{Cf}$. HAYEK, supra note 116 , at 87.

119 See Jon C. Teaford, The Municipal ReVolution in AmeriCA: ORIGINS OF Modern URBAN GOVERNMENT, 1650-1825 23 (University of Chicago Press 1975).
} 
for the simple reason that markets are connected. ${ }^{120}$ How much a trader is willing to pay for a share of stock depends not only on the trader's preferences, but also on the prices of other goods in other markets. ${ }^{121}$ The size of the order a trader is willing to place in the stock market at a given price depends, for example, on the price of gold, not just the price of stocks. ${ }^{122}$ If gold is cheap, for example, the trader might order fewer shares of stock, and buy more gold. ${ }^{123}$ This interdependence of prices can prevent Walrasian auctions from driving prices to efficient levels and instead may drive prices in circles, preventing the market from reaching any equilibrium at all, let alone the efficient one. ${ }^{124}$ When the auctioneer calls out a new price in the stock market, for example, the trader must revise the trader's order in the gold market, which might create excess demand in the gold market, forcing the auctioneer in that market to raise or lower the price, forcing the trader to revise the trader's order in the stock market, triggering a new price in the stock market, and so on. ${ }^{125}$ The cycle can continue indefinitely. ${ }^{126}$

Of course, in real life traders do not pay such careful attention to prices in all markets before making a bid in any one of them, which leads to a second problem with the Walrasian account of how efficient prices are achieved. The problem is that the equation the individual must solve to determine the purchases the individual must make to maximize the individual's happiness is not actually meaningfully simpler than the set of equations the central planner must solve to impose the optimal allocation of resources by fiat. ${ }^{127}$ The individual seeking properly to maximize individual profits must actually know the quality and prices of all of the millions of commodities in the market in order to submit a truly profit-maximizing order for any one product

${ }^{120}$ See Ackerman, supra note 105, at 123.

${ }^{121}$ See VARIAN, supra note 100, at 164-67.

${ }^{122}$ See id.

${ }^{123}$ See id.

${ }^{124}$ See Ackerman, supra note 105, at 121-23.

${ }^{125}$ See Herbert Scarf, Some Examples of Global Instability of the Competitive Equilibrium, 1 INTERNATIONAL ECONOMIC REVIEW 157, 160 (1960).

${ }^{126}$ See id.

${ }^{127}$ To his credit, Hayek seems at time to be aware of this problem, though not apparently of the problem that price adjustments can spiral off and fail to reach equilibrium. See F. A. Hayek, Text, Economics and Knowledge, MISES INSTITUTE, https://mises.org/library/economics-and-knowledge (last visited Jul. 22, 2020) ("price expectations and even the knowledge of current prices are only a very small section of the problem of knowledge as I see it."). But that does not seem to stop him from claiming that market behavior will result in something that sounds awfully like generally equilibrium. See $i d$. (" $[\mathrm{T}]$ he spontaneous actions of individuals will, under conditions which we can define, bring about a distribution of resources which can be understood as if it were made according to a single plan, although nobody has planned it[.]"). 
at the price quoted by the auctioneer in the market for that product. ${ }^{128}$ And the individual must be able to recompute a new bid in response to every price change for every product on sale in the economy. ${ }^{129}$ No economic agent can realistically do that. ${ }^{130}$

So the miracle of the free market, solving massively complex mathematical problems while imposing minimal computational and informational requirements on individuals turned out not to be a miracle after all. ${ }^{131}$ Economic agents myopically placing orders in each market without taking prices in other markets into account will not bid prices to optimal levels. ${ }^{132}$ Moreover, they lack the computational and informational bandwidth to place optimal bids in all markets at the same time, and, even if they did not, that would not lead to optimal prices anyway because each bid depends on every other bid through the effect of each on prices, potentially sending the bidding process spiraling off in infinite regress. ${ }^{133}$ It turned out that to the extent that individuals acting in markets face less of an informational and computational burden than a central planner, that is only because markets are actually less good at achieving optimal results than would be a central planner capable of actually computing solutions to the general equilibrium problem.

In hindsight, it is hard to see how economists could have ever thought that markets could do a better job of finding optima than central planners. ${ }^{134}$ For if the market really were computationally more effective than central planning, then a planner could just set up a big warehouse with one computer dedicated to solving the private profit-maximization problem of each individual, order individuals to upload their preferences into the computers, and then have each computer participate in Walrasian auctions and trade with the others to generate the solution to the general equilibrium problem that direct equation-solving cannot. The reason this cannot be done is that the market is not actually an effective shortcut around the allocation problem. As a computer of optimal allocations, the market is just as imperfect as central planning. Moreover, as the theory of the second-best shows, attempts to get around this problem by approximating a correct solution is a lost cause. ${ }^{135}$ Once any price diverges from the optimum, there is no guarantee that pushing

\footnotetext{
${ }^{128}$ See Ackerman, supra note 105, at 133-34.

${ }^{129}$ See id.

${ }^{130}$ See id.

${ }^{131}$ See id. at 121-23.

${ }^{132}$ See id.

${ }^{133}$ See id. at 121-23, 133-34.

${ }^{134}$ See VARIAN, supra note 100, at 577-78; Shalizi, supra note 115.

135 See R. G. Lipsey \& Kelvin Lancaster, The General Theory of Second Best, 24 THE REVIEW OF ECONOMIC STUDIES 11, 11 (1956); BLAUG, supra note 102, at 600-601.
} 
that price back in the right direction will at least improve efficiency. ${ }^{136}$ Pushing the price even further from the optimum might, perhaps paradoxically, make the economy more productive. ${ }^{137}$

\section{Markets are Learners}

Economics remained in denial about the demise of general equilibrium for decades after the first proofs emerged in the 1970s that no reasonable auction structure was likely to lead to efficient prices. ${ }^{138}$ And although the Great Recession, which followed financial deregulation that was based on general equilibrium models of financial markets, has probably hastened a turn away from theory to empirical work in economics, general-equilibriumstyle thinking remains the principle source of intuition for almost all economists. ${ }^{139}$ But whatever the status of economists' attempts to come to grips with the truth, general equilibrium's collapse does not mean that markets are not computers, or that central planning is just as good a form of economic organization. All general equilibrium's demise means is that the view of markets as solvers of mathematical equations must be abandoned. The market is not a kind of distributed calculation device, generating the optimal solution to the economic allocation problem. But then what is it?

The obvious answer is that markets are machine learning algorithms, processes that continuously update a solution based on new information about how the solution has performed in the past. ${ }^{140}$ Machine learning algorithms - "learners"- differ from traditional computer programs in that the method they employ to solve problems changes over time in response to data. ${ }^{141}$ The learner starts with an initial method, sees the result, then uses a meta-algorithm to alter the method to improve the result. ${ }^{142}$ By contrast, a traditional computer program has an immutable algorithm hard-coded into the program. ${ }^{143}$ The program either generates the desired solution, or it fails. ${ }^{144}$

\footnotetext{
${ }^{136}$ See BlAUG, supra note 102, at 600-601.

137 See id.

${ }^{138}$ See Ackerman, supra note 105, at 124-28.

${ }^{139}$ See Daniel S. Hamermesh, Six Decades of Top Economics Publishing: Who and How?, 51 JoURNAL OF ECONOMIC LitERATURE 162, 168-70 (2013) (describing the turn toward empirical work); Alan Kirman, The Economic Crisis is a Crisis for Economic Theory, 56 CESIFO ECON STUD 498, 515-16 (Oxford Academic Dec. 2010) (noting that empirical work, rather than general equilibrium theory, was confirmed by the 2008 financial crisis).

${ }^{140}$ See Domingos, supra note 60, at 6.

${ }^{141}$ See id. at 6-10.

${ }^{142}$ See id.

${ }^{143}$ See id.

${ }^{144}$ See id.
} 
Consider the problem of finding the length of the diagonal of a rectangle. A traditional computer program provides the right answer if the equation $(\text { Diagonal })^{2}=(\text { Base })^{2}+(\text { Height })^{2}$ is programmed into the computer. If the equation programmed into the computer is incorrect, however, then the program will generate the wrong answer. The program either works or it does not. By contrast, a learner may get the answer wrong, but tries to improve its answer over time. A learner would take information about diagonals of actual triangles that have been measured in the past, for example, and generate a rule from them that it applies to the case at hand. If the computer is told that for a rectangle with base three and height four the diagonal is five, and that for a rectangle with base six and height eight the diagonal is 10 , then the learner might infer that the length of the diagonal is always five times the base divided by three. That explains the data-five times three divided by three is five, and five times six divided by three is ten-but it will not produce the right answer in every case. When the base and height are both one, for example, the diagonal is the square root of two. But once the learned is provided with this additional data, the learner will strive to generate a new rule that explains the new data along with the old. The new rule might just be that in all cases the diagonal is five times the base divided by three except in the case in which the base and height are both one, in which case the diagonal is the square root of two. That would be a highly imperfect method of determining the length of diagonals, but it would be an improvement over the original rule, because it would explain more data.

Machine learning does not require much introduction because human beings are machine learners. We try to infer rules that explain solve our problems based on past experience. When new examples appear that we cannot explain, we tweak the rules to take the new examples into account. The picture of the market as a computer of general equilibria assumes that economic agents subject to property law and seeking to maximize their profits through trade in Walrasian auction markets are a complete solution to the resource allocation problem-they are $(\text { Diagonal })^{2}=(\text { Base })^{2}+$ $(\text { Height })^{2}$ - and so no learning is required to improve the computer's program.

What markets really are, however, are millions of people trying to learn how to improve their welfare. ${ }^{145}$ They try out the method that seems to work

145 Hayek seems at times to argue precisely this. He writes:

The statement that, if people know everything, they are in equilibrium is true simply because that is how we define equilibrium. The assumption of a perfect market in this sense is just another way of saying that equilibrium exists but does not get us any nearer an explanation of when and how such a state will come about. It is clear 
best based on past experience, and then, based on the outcome, they revise their approach. ${ }^{146}$ That makes markets aggregations of interacting machine learners. ${ }^{147}$ In influencing the behavior of these learners, government determines what methods economic agents can use to solve the problem of how to be happy. ${ }^{148}$ Good structures prevent the individual learners from pursuing methods that ultimately harm them or society at large. Bad structures channel learners toward such methods. Economic regulation, then, is a kind of master algorithm that structures the way individuals implement their own personal learning algorithms. ${ }^{149}$

Learners, including the ones individuals employ in daily life, do not just create algorithms to solve problems; they are algorithms themselves. ${ }^{150}$ The

that, if we want to make the assertion that, under certain conditions, people will approach that state, we must explain by what process they will acquire the necessary knowledge. . . The significant point here is that it is these apparently subsidiary hypotheses or assumptions that people do learn from experience, and about how they acquire knowledge, which constitute the empirical content of our propositions about what happens in the real world.

See Hayek, supra note 127 . But at the same time he seems to want to maintain that economic regulation has no role to play in the learning process, and that unaided individual learners will achieve something like the optima of a general equilibrium model. See HAYEK, supra note 116 , at $86-87$.

Authors in the strategic management traditional come much closer to the recognition that the economy is characterized by learning economic agents, but they tend to conceptualize the learning process as the generation of knowledge-based assets or useful information, and they view the role of legal rules such as the law of property not as part of the learning algorithm but as the environmental background against which business evolution takes place. See Mie Augier \& David J. Teece, Strategy as Evolution with Design: The Foundations of Dynamic Capabilities and the Role of Managers in the Economic System, 29 ORGANIZATION STUDIES 1187, 1201-2 (SAGE Publications Ltd Aug. 2008); Mie Augier \& David J. Teece, Dynamic Capabilities and the Role of Managers in Business Strategy and Economic Performance, 20 ORGANIZATION SCIENCE 410, 415 (INFORMS 2009); Edith Tilton Penrose, Biological Analogies in the Theory of the Firm, 42 AM. ECON. REV. 804, 813-16 (American Economic Association 1952); RICHARD R. NELSON, AN EVOLUTIONARY THEORY OF ECONOMIC CHANGE 371 (Harvard University Press Jun. 2009). The difference from the account in this Article is perhaps best described as one of emphasis.

146 See Domingos, supra note 60, at 107-11 (discussing how the brain learns).

${ }^{147}$ See Augier \& Teece, Dynamic Capabilities and the Role of Managers in Business Strategy and Economic Performance, supra note 145, at 415 (stating that "learning enables the organization to use its resources more efficiently").

${ }^{148}$ See NELSON, supra note 145, at 371-72 ("Public laws, policies, and organizations are an important part of the environment that shapes the evolution of private sector activities .").

$149 C f$. Domingos, supra note 60, at 239-46 (using the term "master algorithm in an analogous sense, to describe an algorithm that stitches together different approaches to learning).

${ }^{150}$ See id. at 6-10. 
importance of the learning algorithm - the approach that a machine learner takes to the problem of learning - is evident in our diagonals example. When the learner accounts for the case of the rectangle with base one and height one by treating the resulting diagonal of square root two as an exception to the general rule, the learner takes a flawed approach because exceptions defined in terms of past data cannot be used to predict answers to new questions. ${ }^{151}$ If the algorithm is now asked what the diagonal would be for a rectangle of base five and height seven, the current rule will still provide the wrong answer. Moreover, the case of the rectangle with base one and height one, sequestered into an exception, will not have been used by the learner actually to improve its predictive ability. ${ }^{152} \mathrm{~A}$ better learner is required, one that can use the aberrant case of a rectangle with base one and height one to improve upon the learner's initial general rule that the diagonal is five times the base divided by three. An ancient Indian attempt at the problem produced the formula Diagonal $=\frac{7}{8}$ (base) $+\frac{\text { height }}{2}$, for example, which provides answers for the three cases that diverge from the correct answers by no more than 0.75 , and has the virtue of being able to predict the answers to some other cases with tolerable accuracy as well. ${ }^{153}$ A learner that could generate the ancient Indian formula from those three cases would therefore be an improvement. By the same token, when an economy fails to achieve a desired rate of growth, regulation should change to account for the information this provides about which market ground rules work and which do not.

The original rule applied by humanity to markets was laissez-faire, and that produced nothing: no economic growth for the first 310,000 years of human existence, during most of which humanity pursued an essentially unchanging hunter-gatherer lifestyle. ${ }^{154}$ Then after a period of transition to small-scale farming, humanity tried central planning, and the results were astonishing. Civilization appeared for the first time, starting about 6,000

\footnotetext{
151 See id. at 71 .

152 See id.

153 See Triangles - Pythagorean Theorem Expressed without Roots in an Old Tamilian (Indian) Statement, MATHEMATICS STACK ExCHANGE, https://math.stackexchange.com/questions/1351706/pythagorean-theorem-expressedwithout-roots-in-an-old-tamilian-indian-statemen (last visited Jul. 23, 2020).

154 The figure is obtained by subtracting the most recent 10,000 years of human history, roughly during which human populations started to grow nonlinearly in size, presumably reflecting adoption of agriculture, from the 320,000 years since the death of humanity's most recent common ancestor. See DAVID REICH, WhO We ARE AND How We Got Here: ANCIENT DNA AND THE NEW SCIENCE OF THE HuMAN PAST 2 (2018) (providing the 320,000 year figure); Brad DeLong, Estimates of World GDP, One Million B.C.-Present 1 (providing the 10,000 year figure).
} 
years ago, and world GDP started to increase nonlinearly. ${ }^{155}$ Then, about 200 years ago, human ingenuity took off. ${ }^{156}$ Although several attempts were made to harness this with central planning, we learned that a modified regime, one that preserves the prohibition on theft contained in all planning regimes, but which allows considerably more individual initiative, seems to do a better job. ${ }^{157}$ The result was more economic growth. ${ }^{158}$ The question is whether any other changes might lead to further improvements.

This point may seem trivial. Of course people learn and policymakers learn and humanity should be on the lookout for improvements. But that is just the point of this Article: that in opposing antitrust and regulation the Chicago School denied learning. Rather than treat continued programming and adjustment of the ground rules for economic activity as a good, the Chicago school sought to freeze that learning activity, to transform a learner into a traditional computer program, and a failed one at that, as the demise of general equilibrium shows. ${ }^{159}$ While many Chicago positions seemed innovative - adoption markets, for example - they were innovative only in that they sought to take the formula of laissez-faire plus property rights to the most extreme possible conclusion, replacing the old central planning default entirely. ${ }^{160}$ And yet there is one obvious extension of the concept of property rights, one that can only be executed through more antitrust enforcement, that could well represent an improvement upon the property regime that is the principal content of the learning algorithm society has in place today. ${ }^{161}$ But Chicago could not entertain any extensions, because it rejected the entire concept of learning at the level of market organization as interference with

\footnotetext{
155 See DeLong, supra note 154, at 7 (showing GDP start to double every thousand years in the ancient world after $4000 \mathrm{BC}$ ).

156 See Robert C. Allen, Global EcOnOmic History: A Very SHORT InTROdUCtion 23 (Oxford University Press 2011) (discussing the Industrial Revolution); JOEL MOKYR, THE ENLIGHTENED ECONOMY: AN ECONOMIC History OF BRITAIN, 1700-1850 9-10 (Yale University Press 2009) (attributing the Industrial Revolution to a flowering of technological innovation).

157 See ALLEN, supra note 156, at 132-35, 139-41 (discussing Russian and Chinese experimentation with central planning); AliCE H. AMSDEN, THE RISE OF "THE REST": CHALlenges to THE WeSt FROM LATE-INDUSTRIALIZING ECONOMIES (Oxford Univ. Press 2009) (discussing the path to growth taken by Asian countries employing a mix of markets and planning).

158 See ALLEN, supra note 156, at 143-45 (discussing China's growth success after abandoning planning).

159 See supra Sections IV, V.A.1.

160 See Fancesco Parisi \& Ben W. F. Depoorter, Private Choices and Public Law: Richard A. Posner's Contributions to Family Law and Policy, 17 J. CONTEMP. HeAlth L. \& PoL'Y 403, 410-11 (2001) (discussing a proposal of Richard Posner).

${ }^{161}$ See infra Section V.C.
} 
what it believed to be the original and most natural state of markets. ${ }^{162}$ But to understand how antitrust of the right sort might represent a further improvement on the market algorithm, it is necessary to go back and start the story of that algorithm from the very beginning, considering its progress in greater detail. This exploration will show how property rights channel learning in good directions, and lay the groundwork for a demonstration of how a certain approach to the antitrust laws can improve upon property rights. ${ }^{163}$

\section{B. The History of Economic Algorithms}

\section{The Market in the State of Nature}

In the beginning, there were markets, but there were no property rights, at least as we understand property rights today. ${ }^{164}$ There were people who made things, and sold them, and there were people who acquired things by making purchases, just as one finds in any market. ${ }^{165}$ But the absence of property rights meant that, in contrast to the markets of today, goods and services could generally be acquired from others other than by means of exchange: goods and services could be acquired by putting their possessors to the sword, or threatening to do so. ${ }^{166}$ The existence of this second option in the time before law has tended to blind both the left and the right to the fact that the first option, exchange, always existed, that markets can and do exist without law. ${ }^{167}$ Xenophon, in his history, Anabasis, provides a taste of these two options in recalling his speech to the Greek mercenaries when they arrived at Trapezus, on the shores of the Black Sea:

"[W]e have to get our provisions from enemy country, as there is not sufficient food available in the market, nor have

\footnotetext{
162 See supra Sections IV.

163 That demonstration is the subject of Section V.C.

164 See COOTER \& ULEN, supra note 71, at 77-78.

165 See id.

166 See id.; STEVEn PinKer, THE BetTer ANGels of OUR NATURE: A HiSTORY OF ViOLENCE AND HUMANITY 47-56 (2012) (reviewing evidence that ancient societies were considerably more violent than society is today).

167 See Robert L. Hale, Our Equivocal Constitutional Guaranties. Treacherous Safeguards of Liberty, 39 COLUM. L. REV. 563, 587-88 (Columbia Law Review Association, Inc. 1939) (arguing that property is created by the state); BARBARA FRIED, THE PROGRESSIVE ASSAULT ON LAISSEZ FAIRE: ROBERT HALE AND THE FIRST LAW AND ECONOMICS MOVEMENT 80-81, 172-73 (Harvard Univ. Pr. 1998) (reviewing progressive arguments that property is created by the state); Harold Demsetz, Toward a Theory of Property Rights, 57 AM. ECON. REV. 347, 351-52 (May 1967) (suggesting that trade was alien to hunter-gatherer societies).
} 
we, except for a few of us, enough money to buy what there is. The country round us is hostile, and therefore, if you do your foraging in a slack and unorganized way, there is danger of us losing a lot of men."168

The market always did exist in the state of nature, even if arms were an alternative to it. ${ }^{169}$ The left seems not to understand this, however, when the left argues that the government creates property rights and therefore has a right to take them away. ${ }^{170}$ Tell that to the settler, whose property rights grow from the barrel of a gun. Or indeed to Xenophon, who took dominion and control over the slaves and oxen of Asidates the Persian in the face of withering counterattack that injured half of his men. ${ }^{171}$ Before government and law, people still exercised dominion and control over things, they just did not rely on governments for help in maintaining that control. ${ }^{172}$

The right, in the form of the Chicago School, makes the same mistake of assuming the absence of markets before law when the right argues that markets will allocate resources properly so long as property rights are well defined. ${ }^{173}$ Chicago means to say that if property rights are not well defined then a producer will need to spend extra money defending the producer's claim to his goods, and that extra money might make production unprofitable, causing the producer to stop producing. ${ }^{174}$ It seems to follow that markets cannot function without property rights. ${ }^{175}$ But that is to confuse static with dynamic efficiency. ${ }^{176} \mathrm{~A}$ market is efficient in the static sense if the market allocates goods and services to their most valuable uses given the prevailing level of technology. ${ }^{177}$ The economy of 1980 could have been statically

168 See Xenophon, The Persian Expedition. 221 (George Cawkwell ed., Rex Warner trans., Penguin Books 1972).

169 See Moses I. Finley \& IAN Morris, The AnCIENT ECONOMY (Univ. of Calif. Press 2009).

${ }^{170}$ See Hale, supra note 167, at 587-88; FRIED, supra note 167, at 80-81, 172-73.

171 See XENOPHON, supra note 168, at 349-50.

172 See Bruce D. Smith, A Cultural Niche Construction Theory of Initial Domestication 26364 (2012) ("Ownership of a wide variety of different types of such high-value resource locales or patches within the resource catchments of small-scale societies has been ocumented, including settings as diverse as particular stretches of beach associated with clam beds, seasonal fish-run river bottlenecks, root 'gardens,' and pinon groves or even individual pinon trees.").Hayek emphasizes this point, although Chicago seems not to have internalized it. Compare HAYEK, supra note 116, at 43 (asserting: "trade older than the state"); with Demsetz, supra note 167, at 351-52.

173 See VARIAN, supra note 100 , at 630.

${ }^{174}$ See id. at 627-37.

175 See id.

176 See COOTER \& ULEN, supra note 71, at 116-17.

177 See Sidak \& Teece, supra note 46, at 585-90. 
efficient if it ensured that those who placed the highest value on landline telephone were able to place calls, even though the economy could not grant anyone access to the far more efficient calling functionality offered by the iPhone, because the iPhone had not yet been invented. An economy is efficient in the dynamic sense if the economy is maintaining an optimal rate of technological innovation, after accounting for both the costs of innovation and benefits, in terms of the new production opportunities that innovation makes possible. ${ }^{178}$ Chicago's observation that well-defined property rights are required for some forms of production to be profitable is no more than the observation that property rights are in effect a technological innovation: they create new production opportunities, and in this sense are dynamically efficient. But that does not mean that the markets that exist in the state of nature, in the absence of property rights, cannot allocate goods and services to their most productive uses given the prevailing level of technology, including the absence of that particular innovation known as the state. Only that in the state of nature the costs of security limit what can be produced, just as in 1980 the absence of the iPhone prevented some communications, and the value they might have created, from taking place. ${ }^{179}$

The real significance of property rights - missed by both government fundamentalism on the left and the cult of the well-defined right on the right - is not that they make markets possible, but that they make markets better. They do this not only by reducing production costs, realizing the economies of scale associated with paying a single security force-the police - to protect everyone's property, but through a second and more important channel: property rights strengthen consumer sovereignty, ensuring that consumers are able to send strong signals regarding their preferences through to producers. ${ }^{180}$ The consumer who cannot steal must reward producers for making what the consumer prefers, and the producer who cannot steal the output of others must produce what consumers prefer in

\footnotetext{
${ }^{178}$ See id.; David J. Teece \& Mary Coleman, The Meaning of Monopoly: Antitrust Analysis in High-Technology Industries, 43 ANTITRUST Bull. 801, 810-12 (1998); JOSEPH A. SCHUMPETER, CAPITALISM, SOCIALISM, AND DEMOCRACY 81-86 (Routledge 1994); Denicolò, supra note 7, at 689-91 (providing a mathematical condition for such an optimum, under restrictive assumptions, of course).

${ }^{179}$ Cf. VARIAN, supra note 100, at 627-37.

180 See Neil W. Averitt \& Robert H. Lande, Consumer Sovereignty: A Unified Theory of Antitrust and Consumer Protection Law, 65 ANTITRUST L.J. 713, 715-16 (1997) (discussing consumer sovereignty); Abba P. Lerner, The Economics and Politics of Consumer Sovereignty, 62 AM. ECON. REV. 258, 258 (1972) (ditto); COOTER \& ULEN, supra note 71, at 77-78 (discussing the security rationale); Frederic C. Lane, Economic Consequences of Organized Violence, 18 J. ECON. HIST. 401, 402 (Cambridge University Press 1958) ("A monopoly of the use of force within a contiguous territory enable[s] a protection-producing enterprise to improve its product and reduce its costs.").
} 
order to earn the consumer's rewards, ensuring that producers make what consumers value most. ${ }^{181}$

The state of nature is a learning algorithm that enables agents to pursue private wealth maximization through either exchange or theft. At each moment, agents go out into the world and, based on past experience, seek to obtain what they want through a combination of these two strategies, and the sum total of their and all other agents' behaviors in that moment represents the particular program that the learner has learned at that moment. ${ }^{182}$ In the next moment, agents update their strategies based on the results, and the program changes. ${ }^{183}$ The introduction of property rights represents a change to this learning algorithm. ${ }^{184}$ Property rights tell the learning algorithm to take the theft option away from agents. That limits what agents can learn to do in a way that causes the conduct they learn to undertake better to allocate resources efficiently.

\section{The Tragedy of Theft in Nature}

The power of property rights, and the discouragement of theft that they imply, to ensure that markets produce what consumers want becomes clearest once the frame around human interactions in the state of nature is removed and all natural life is considered. All of nature faces the same two options as does humanity in the absence of law, whether to exchange-sometimes called a symbiosis by biologists - or to steal—called predation by biologists - and it is because nature has no rule against theft that nature has over time produced what may be the darkest of all market outcomes: us. ${ }^{185}$ Evolutionary biologists refer to the Ediacaran Age, the epoch when multicellular life first appeared on earth, as the "Garden of Ediacara," because one element that would characterize all subsequent ages was missing: predators. ${ }^{186}$ The small sponge-like creatures that characterized this

181 See RichARd A POSNER, ECONOMIC ANALYSIS OF LAW (Wolters Kluwer for Aspen Publishers 7th ed. 2007); Ramsi A. Woodcock, Property, Efficiency, the Commons, and Theft, in RESEARCH HANDBOOK ON POLITICAL ECONOMY AND LAW 531 (Ugo Mattei \& John D. Haskell eds., Edward Elgar 2015).

182 See DoMINGOS, supra note 60, at 6-10.

${ }^{183}$ See id.

${ }^{184}$ See id.

185 See Nick LANE, LiFE AsCending: THE TEN GREAT InVENTIONS OF EVOLUTION 61-62, 111 (W. W. Norton \& Company Jun. 2010) (defining symbiosis and predation); DAVID WAllace-Wells, The Uninhabitable EARTH: LifE AFTER WARMing (Crown Feb. 2019) (describing the consequences of manmade climate change).

186 See Peter Godfrey-Smith, Other Minds: The OCTOPUS AND THE Evolution of INTELLIGENT LIFE 32 (Farrar, Straus and Giroux 2016). 
age fed on algae but not on each other. ${ }^{187}$ That made the Ediacaran much like the markets that policymakers try to create today, in which firms can only succeed by producing better products, and not by stealing from others. But the Ediacaran did not last. ${ }^{188}$ Lacking legal rules preventing creatures from evolving to live off each other, life evolved predators, giving rise to the proliferation of armored and armed life known as the "Cambrian explosion," during which the ancestors of virtually all of the mobile animals with which we are familiar today first emerged. ${ }^{189}$

Predators take without paying. The arctic wolf contributes nothing to the musk ox, for example, unless we take the strained position that in taking some of the musk ox's young, the wolf keeps the adult musk ox population in check, ensuring that there is enough tundra grass for everyone. ${ }^{190}$ But who needs the wolf when starvation solves that problem on its own? The only thing that stops predation from shutting down the market entirely by wiping out the prey is the wasteful expenditure of resources by the prey upon selfdefense. ${ }^{191}$ Thus the celebrated equilibrium of ecosystems, in which the defensive strategies of the prey are so finely balanced against the predation strategies of the predator that year after year both populations remain stable represents an immense failure. It is an equilibrium in violent redistribution, rather than an equilibrium achieved through mutually beneficial exchange. If the wolf has nothing to offer the ox, then the wolf should starve, and make way for the creature that can work with the ox to expand the production possibilities frontier of the natural world. ${ }^{192}$ The wolf should make way for a creature that can turn the zero-sum interactions of predators and prey, in which they compete to determine which retains the energy locked in the biomass produced by the musk ox, into positive sum interactions in which in exchange for a pound of the musk ox's flesh-or perhaps some bovid service - the creature provides the musk ox with something that increases the amount of energy the musk ox is able to extract from grasses. ${ }^{193}$

\footnotetext{
${ }^{187}$ See id. at 27-33.

188 See id. at 33-34.

189 See id.; STEPHEN JAy Gould, Wonderful LifE: The Burgess Shale AND the NATURE OF HISTORY 24 (2007).

190 See generally L. David Mech, Decline and Recovery of a High Arctic Wolf-Prey System, 58 ARCTIC 305 (Arctic Institute of North America 2005) (discussing the relationship between arctic wolves and musk oxen). The arctic hare also plays an important role in this ecosystem, but for simplicity I leave it out of this thought experiment. See L. David Mech, Annual Arctic Wolf Pack Size Related to Arctic Hare Numbers, 60 ARCTIC 309, 310-11 (Arctic Institute of North America 2007).

${ }^{191}$ See LANE, supra note 185 , at 147.

192 See VARIAN, supra note 100, at 600-602 (discussing the concept of the production possibilities frontier in economics).

193 See Nicholas C. Larter \& John A. Nagy, Peary Caribou, Muskoxen and Banks Island
} 
To be sure, evolution is not without its moments of symbiosis, the flowering plants being the most famous example. ${ }^{194}$ The plant makes nectar, and creates an advertisement - the flower-to show creatures where to find this product. ${ }^{195}$ In exchange the creatures that do find the nectar carry out the useful function of distributing the plant's seeds. ${ }^{196}$ Bees participate in this exchange: pollen rubs off on their legs when they feed on the nectar, for example. ${ }^{197}$ But primates and even modern humans do too, for color vision is said to have evolved in primates to allow us to identify the flowers of fruiting trees, the seeds of which we distribute in our droppings. ${ }^{198}$ Indeed, many of the attributes of modern marketing can be seen in this relationship, for once a particular plant hooks a particular client, an evolutionary spiral can ensue, in which the client becomes increasingly reliant on the plant, locking the client in and sheltering the plant from competition from other plants, and the plant in turn rewards that reliance, by further specializing itself to meet the needs of the client. ${ }^{199}$ The result is Darwin's famous moth-and-orchid pair, the former having a tongue so long that only it can reach the orchid's nectar and the orchid having a neck so long that no other moth can access it, ensuring that both the orchid and the moth have in the other a reliable collaborator. ${ }^{200}$ There is no daylight between this scheme and the practice of product differentiation in the business world. ${ }^{201}$ Just so, the car industry induced consumers to move to suburbs and then built them massive SUVs that can only conveniently be parked in them. Or coffee companies induce a morning routine that they serve with powerful espressos that only coffee drinkers can enjoy.

Human beings deserve credit for advancing symbiosis in nature, not just in their dealings with each other-there is no cooperation between wolf packs, for example, but there has been trade between tribes of human beings

Forage: Assessing Seasonal Diet Similarities, RANGIFER 9, 13 (1997) (discussing the musk ox's diet).

194 See LANE, supra note 185, at 121.

195 See id.

196 See id.

197 See Christian Westerkamp, Honeybees Are Poor Pollinators — Why?, 177 PLANT Systematics AND Evolution 71, 73 (Mar. 1991).

198 See Brian C. Verrelli et al., Different Selective Pressures Shape the Molecular Evolution of Color Vision in Chimpanzee and Human Populations, 25 MOLECULAR BIOLOGY AND EVOLUTION 2735 (Oxford Academic Dec. 2008); LANE, supra note 185, at 147.

${ }^{199}$ See Dave Hone, Moth Tongues, Orchids and Darwin-the Predictive Power of Evolution, THE GUARDIAN, http://www.theguardian.com/science/lost-worlds/2013/oct/02/mothtongues-orchids-darwin-evolution (last visited Jul. 24, 2020).

${ }^{200}$ See id.

201 See CHAmBerlin, supra note 12, at 56-70 (discussing product differentiation and monopolistic competition). 
going back to the dawn of the species 320,000 years ago-but also in their dealings with other creatures. ${ }^{202}$ For the domestication of livestock and plants practiced by human civilization is a form of inter-specie symbiosis, albeit one that sounds very much more in the mode of slavery than free exchange. ${ }^{203}$ Too weak to demand basic political rights, domesticated plants and animals have only their biology as a negotiating position: human beings must provide them with enough compensation - food, water, soil, and so on - to ensure their survival, and spread into areas to which humans want them to spread, but need not provide them with any more than that. Thus a gardener plants tomatoes in the raised beds in her garden, but ruthlessly pulls up any seedlings spread by birds that may appear on her lawn. Just so, a slave may be said to transact, in the sense that the master provides just enough compensation in the form of food to keep the slave working, but the political oppression of the slave means that he lacks alternatives to working for the master and so cannot use his intelligence and motility to withhold labor until he extracts a better deal, with the result that the slave's minimum biological needs become the only limits on the ability of the master to exploit him, as those limits determine the slave's one alternative: death.

Despite the morally reprehensible characteristic of domestication that it arrogates to the domesticator all of the gains from trade, the fact that domestication is trade - a symbiosis - means that it differs fundamentally from predation. ${ }^{204}$ The wolf, it is true, does not drive the musk ox to extinction, but that is only because the musk ox is able to defend itself. ${ }^{205}$ If for some reason the adult musk ox were to stop wheeling upon and scattering pursuing wolves, the wolves would kill on every hunt, and the musk ox would disappear. ${ }^{206}$ By contrast, the domesticator does not drive the population of

\footnotetext{
202 See Lorraine Boissoneault, Colored Pigments and Complex Tools Suggest Humans Were Trading 100,000 Years Earlier Than Previously Believed, SMITHSONIAN MAGAZINE, https://www.smithsonianmag.com/science-nature/colored-pigments-and-complex-toolssuggest-human-trade-100000-years-earlier-previously-believed-180968499/ (last visited Jul. 24, 2020).

203 See Simone Riehl et al., Emergence of Agriculture in the Foothills of the Zagros Mountains of Iran, 341 SCI. 65, 65 (American Association for the Advancement of Science Jul. 2013) (dating plant domestication to about 10,000 years ago); Emily Jane McTavish et al., New World Cattle Show Ancestry from Multiple Independent Domestication Events, 110 ProceEdings of THE NATIONAL ACADEMy OF SCIENCES OF THE UNITED STATES OF AMERICA E1398, E1398 (Apr. 2013) (showing that cattle were domesticated at about the same time).

204 See LANE, supra note 185, at 121 (defining symbiosis).

205 See David R. Gray, The Killing of a Bull Muskox by a Single Wolf, 23 ARCTIC 197, 19798 (Arctic Institute of North America 1970) (describing a musk ox's defensive behaviors). ${ }^{206}$ See John Simpson Tener, A Preliminary Study of the Musk-Oxen of Slidre Fiord District, Fosheim Peninsula, Ellesmere Island 44 (University of British Columbia 1952) (discussing
} 
the domesticated creature to zero. ${ }^{207}$ There is in domestication a recognition that in not taking everything from the creature, in preserving it and expanding its footprint, the domesticator is made better off than the domesticator would be by engaging in mere predation. ${ }^{208}$ The success of this innovation in human behavior is reflected in the triumph and plenty of the institution of human civilization to which it gave rise, relative to the poverty of the hunter-gatherer lifestyle that it displaced. ${ }^{209}$

If nature had prohibited theft, then there would be no predation, and all of the power of evolutionary forces would have been forced through two remaining channels, that involving the generation of energy from inanimate matter, as plants do from light and bacteria can do from a host of substances including methane and sulphate, and that of increasing the efficiency with which that energy is exploited through symbiosis or trade. ${ }^{210}$ Both are productive, increasing the amount of energy generated by life, or the efficiency with which life exploits it, in contrast to theft, which just squanders and redistributes that energy. ${ }^{211}$ The absence of a rule against theft in nature has meant that eons of evolutionary time have been wasted on arms races between predators and prey that have done little to advance the project of extracting and exploiting energy, of animating the inanimate to the greatest

musk ox defense behaviors).

${ }^{207}$ See Smith, supra note 172, at 266.

208 See id.

${ }^{209}$ See id. at 260 (identifying domestication as the root of contemporary human plenty). It was only once domestication of plants and animals, which started about 10,000 years ago, was combined with the domestication of human beings that was the foundation of the centrally planned civilizations that emerged about 6000 years ago, that the huge output increases made possible by domestication become evidence in economic data. See DeLong, supra note 154, at 7 (showing GDP start to double every thousand years in the ancient world after $4000 \mathrm{BC}$ ); Smith, supra note 172, at 260 (dating the start of domestication to 10,000 years ago); J. G MANNING, OPEN SEA: THE ECONOMIC LIFE OF THE ANCIENT MEDITERRANEAN WORLD FROM THE IRON AGE TO THE ... RISE OF ROME. 127-34 (PRINCETON University PRES 2020) (describing labor in ancient civilization as ranging from "tenant farming" to "slave labor"); BENJAMIN R FOSTER \& KAREN POLINGER FOSTER, CivilizATIONS OF ANCIENT IRAQ 15-17 (Princeton University Press 2011) (dating the birth of civilization to Uruk in $3600 \mathrm{BC}$ ).

${ }^{210}$ See LANE, supra note 185, at 60-61 (discussing ways in which life generates energy); VARIAN, supra note 100, at 15-16 (discussing the efficiency of trade in economic terms).

211 In economic terms, theft creates an externality that undermines efficiency, and the enforcement of property rights eliminates the externality. See MAS-COLELL ET AL., supra note 101 , at 352-57. Theft inflicts a negative externality - an uncompensated harm-on the victim. Giving the thief a right to steal, which is tantamount to giving the thief a legallyenforceable property right over the stolen item, or giving the victim a right to prohibit stealing, which is tantamount to giving the victim a legally-enforceable property right over the stolen item, eliminates the inefficiency. See Woodcock, supra note 181, at 553-54. 
possible degree, that is the business of life. ${ }^{212}$ One can only imagine the heights that multicellular life might have reached over the half billion years after the Ediacaran if the laissez-faire of nature had not prevailed and a filter feeder could have gotten ahead only by tapping some new inanimate store of energy or working with other creatures. ${ }^{213}$ Would human cells generate their own chlorophyll by now, for example, and therefore not need climatedestroying carbon-intensive activities like farming and animal husbandry to keep them nourished? ${ }^{214}$ Perhaps. Indeed, there might be no need for hot blood, that original carbon-intensive energy process that turns mammals and birds into throbbing dynamos radiating heat even while at rest in order to make possible the stamina required to outrun predators or run prey to exhaustion. $^{215}$ Evolution in nature could not avoid such waste, because it is unregulated. Evolution serves not to support a laissez-faire economic program, but to caution against one. ${ }^{216}$

Indeed, today one can hardly even point to humanity itself as an example of the good that laissez-faire can produce. To be sure, the fact that we evolved civilization, which amounts to symbiosis as a basic behavioral trait, is evidence that the laissez-faire that culminated in us is not all bad-not all predation and exploitation-even if our own symbiotic moment, no more than 10,000 years old, has endured for less than the blink of an eye in our own lifespan as a species. ${ }^{217}$ But in the last 200 years we have sought to push beyond the energy gains created by agriculture and animal husbandry to generate energy from inanimate matter itself, leading to the burning of fossil fuels and climate cataclysm. ${ }^{218}$ That cataclysm is driven by our inability to access the energy of inanimate matter directly, which in turn is an expression of the abject failure of evolution. For our inability to access the energy of

212 See Vaclav Smil, World History and Energy, in ENCYCLOPEDIA OF ENERGY 549, 561 (Elsevier 2004) ("[T]hermodynamics requires that higher socioeconomic complexity must be supported by more intensive flows of energy.").

213 See GODFREY-SMITH, supra note 186, at 28.

${ }^{214}$ See WALLACE-WELLS, supra note 185.

215 See LANE, supra note 185, at 208, 210-13.

${ }^{216} C f$. HAYEK, supra note 116 , at 15 (stating that "evolutionary change in general tends towards a maximum economy in the use of resources") (internal quotation marks omitted); Sidak \& Teece, supra note 46, at 605-7; Armen A. Alchian, Uncertainty, Evolution, and Economic Theory, 58 Journal OF POLITICAL ECONOMY 211, 220-21 (University of Chicago Press 1950) (arguing that natural selection causes firms to maximize profits even when they do not intend to do so, but failing to acknowledge the role of property rights in achieving this evolutionary outcome).

217 See Smith, supra note 172, at 260; REICH, supra note 154, at 2.

${ }^{218}$ See ALLEN, supra note 156, at 27 (dating the Industrial Revolution to the period 1760 to 1850); Smil, supra note 212, at 552, 554-56 (describing the history of the global transition to fossil fuels starting in the 18th century); WALLACE-WELLS, supra note 185. 
inanimate matter directly arises because our bloodline made a living by stealing the energy produced by others, and so did not need to incorporate the biological processes used by plants and bacteria for generating energy directly from the physical world. ${ }^{219}$

Of course, one might view humanity's discovery of technological means to generate energy from inanimate matter as itself a kind of saving grace, in which a predator eventually turns its back on predation, and even on the inequities of domestication, and returns to the benevolence and productivity of the Ediacaran. But humanity has so far failed actually to find a sustainable way to generate energy, and is on track to wipe itself, and perhaps all life, out if it continues to pursue the present course of generation of energy from burning of fossil fuels. ${ }^{220}$ Moreover, it is equally clear that more laissez-faire will not solve the problem, as individuals, unregulated, will continue to burn fossil fuels until the human habitat is no more, just as the wolf pack, without pushback, would eat the musk ox to extinction if it could, and then starve. Human ingenuity might birth sustainable energy in time to save the day, but that increasingly looks like wishful thinking, and is more likely to be so the less regulated our markets and the more prevalent are incentive-destroying practices like theft. ${ }^{221}$ So in humanity, and the climate cataclysm humanity has spawned, one might justly say that we have the starkest possible example of the deficiency of laissez-faire evolution, one that, in its toleration of predation, can give rise to creations that destroy life itself.

Chicago School authors appear unaware both of the great deficiencies of evolution as a learning algorithm and even that Chicago's own preferred algorithm, that of laissez-faire plus property rights, is not the same thing as the laissez-faire without property rights that is evolution. ${ }^{222}$ Instead, Chicago occasionally holds up evolution as a triumph, and support for Chicago's case for free markets. ${ }^{223}$ By that logic, however, Chicago should oppose the institution of property itself, and celebrate the successful thief to the same extent as Chicago celebrates the successful entrepreneur. Chicago does not do that because it recognizes that humanity was right 10,000 years ago to learn domestication - inter-species trade - and right again to learn property

\footnotetext{
219 See LANE, supra note 185, at 144-46 (discussing the relationship between motility and predation).

${ }^{220}$ See WALLACE-WELLS, supra note 185.

221 The great the regulation of fossil fuels, the greater the cost of using them, and the greater the incentive to invent other methods of extracting energy. See Joshua Meltzer, A Carbon Tax as a Driver of Green Technology Innovation and the Implications for International Trade, 35 ENERGY L.J. 45, 52-53 (2014). Theft of course reduces the incentive to innovate. See RichARD POSNER, ECONOMIC ANALYSIS OF LAW 30 (Little, Brown 1986).

${ }^{222}$ See supra sources cited in note 216.

${ }^{223}$ See supra sources cited in note 216.
} 
and the inducement to trade between human beings that creates. ${ }^{224}$ Why that should exhaust the learning opportunities of the economy, as Chicago suggests in advocating preservation of the liberal status quote, is not clear. ${ }^{225}$

\section{From Central Planning to Property Rights}

But before property rights came planning. Civilization was a watershed in symbiotic behavior for humanity because it took humanity beyond the symbiosis with plants and animals via domestication to a strengthening of symbiotic behavior between human beings. ${ }^{226}$ The image of civilization, that of great masses of people living and working together, is an expression of the symbioticism at the core of that concept. At first, however, humanity practiced the new symbioticism in relation to other human beings in the manner in which humanity practiced it in relation to plants and animals: more as domestication than as voluntary trade. For the hallmark of the emergence of civilization was planning. ${ }^{227}$ Here, for example, is how the Third Dynasty of Ur did it 5,000 years ago:

The foundations of this society rested upon tens of thousands of workers, those of menial status sustained by the distribution of a bare living ration of raw staplesbarley, wool, and vegetable oil — and those of higher status, such as administrators and officials, receiving finished products, including bread and other baked goods, beer, textiles, and processed animal fats. Laborers in fields,

${ }^{224}$ See Demsetz, supra note 167, at 347-53.

225 See supra Part IV.

${ }^{226}$ For domestication, see supra Section V.B.2.

${ }^{227}$ Consider this description of Egypt in the Fourth Dynasty, when the first monumental pyramids were constructed:

New styles of pottery and sculpture were promulgated by the court to be produced [for the first time] in state workshops. New towns were founded by the state to replace the earlier centers of power . . . . It is tempting to see these phenomena as parts of a deliberate and coordinated government policy designed to snuff out local autonomy and replace it with a new, absolute dependency on central authority. Even in the mortuary sphere, the king's commanding presence held sway. Anyone with any position whatsoever in the vast machinery of government now sought to be buried in the court cemetery, funded by the king and dominated by his own gigantic funerary monument, rather than being interred in their local burial ground, hallowed by age and ancestral ties.

See Toby A. H Wilkinson, The Rise And Fall of Ancient Egypt 59 (Random House Trade Paperbacks 2013). 
irrigation works, flour mills, breweries, bakeries, and boat yards toiled long days in large teams to meet fixed quotas of output. The king's bureaucrats could calculate exactly the expenses and work needs of a project, estimating to a nicety how much time it would take to clear weeds from a given set of fields, how many workers and how much seed would be required to cultivate it, and what the fields would yield. Backbreaking work was to be signed and sealed for, like any other commodity. Moreover, the administration had detailed schemes of tasks and output. For each major temple complex, for example, scribes knew how much land was available and what condition it was in. They could compute the harvest in advance by comparing the previous records with the present state of the fields. Gathering the information from many such temple complexes and considering the land as a whole, they could even compute regional expectations on the basis of past performance. ... Private initiative was stifled by restricting the sale of land. ${ }^{228}$

Although not often recognized, planning has in common with markets a strict prohibition on theft. So, like market economies, centrally planned economies channel productive activity into exchange rather than predation and theft. To modern eyes unused to distinguishing a subsistence wage from outright theft - a working of the laborer to death - this may seem like no advance at all. ${ }^{229}$ But the contrast between the first civilizations and the

${ }^{228}$ FOSTER \& FOSTER, supra note 209, at 67-68. The same prevailed in Egypt a thousand years earlier. WILKINSON, supra note 227, at 44-46, 342 ("The government's ambition [was] to control every aspect of the national economy.").

${ }^{229}$ Theft in the legal sense is of course a taking of the property of others without permission. Technically, it is trespass to personal or real property, or infringement of intellectual property. See JeSSE DUKEMINIER ET AL., PROPERTY 88-96 (Aspen Publishers 7th ed. 2010); Robert P Merges et Al., InTEllectual Property in THE NEW TECHNOLOGICAL Age 2431 (Wolters Kluwer 6th ed. 2012). The non-existence of a license to engage in the trespass, reflecting the involuntariness of the appropriation, is key. See DUKEMINIER ET AL., supra, at 773-74; MERGES ET AL., supra, at 28. But from an economic perspective, one in which the concept of voluntariness plays no role, theft is a matter of the terms according to which thief and victim deal with each other.

If the thief takes but pays a price in excess of the economic cost of the property to the victim, then in the economic sense there is no theft, but only a trade. It is, to borrow from the concept of efficient breach in contract law, an efficient trespass, an exchange that, though forced, is nonetheless fair and indeed good for the economy because the taker's willingness to pay more than the cost of the property implies that the taker must place a higher value upon the property than does the victim, the victim's cost in the economic sense being 
hunter-gatherers and small-scale agricultural communities they replaced says otherwise. $^{230}$ The great increase in plenty leaps out from world population estimates, which show world population, stagnant for tens of thousands of years, increase by $40 \%$ as the first civilizations started to grow after about $3000 \mathrm{BC}$, then double in the following millennium, and double again in the millennium after that. ${ }^{231}$

Central planning works well when civilizations are still small enough to approximate the size of today's larger corporations, and when technology is still so rudimentary that civilization's productive energies retain the narrow focus of today's corporations as well. ${ }^{232}$ Third century Ur, population 65,000,

precisely the value that the victim places on the property. See Douglas LAYCOCK, MODERN AMERICAN REMEDIES: CASES AND MATERIALS 396-400 (Aspen Publishers 4th ed. 2010). If, by contrast, the thief takes and pays a price less than the economic cost of the property to the victim, then there is theft in the economic sense of a taking that is not for fair value. This sort of taking is not just unfair to the victim, who ends up worse off as a result of the taking, but also bad for the economy, because it destroys the victim's incentive to work and produce, serving as a warning that the victim will not receive compensation for the victim's productive activities. The laborer who is worked to death is not provided even with the bare minimum of compensation required for survival and so is a victim of theft in the economic sense.

This distinction between takings not for cost as theft and takings for compensation in excess of cost as mere trade is reflected in the practice of courts of awarding damages for trespass equal only to the economic cost of the property to the victim, rather than for damages that include some economic profits for the victim. See id. at 22-23 (observing that the general rule of damages measurement is to value damages at the market price of the item, meaning the cost that would be incurred in acquiring it on the market); Ramsi A. Woodcock, Damages as Personalized Pricing in Favor of Wrongdoers-What Am I Missing?, https://zephyranth.pw/2020/07/06/damages-as-personalized-pricing-in-favor-of-

wrongdoers/. That suggests that what troubles courts about trespass is the possibility that it may constitute theft in the economic sense of a taking not in exchange for the payment of costs. Of course, courts will usually enjoin the thief to end the trespass - to return the stolen property, for example - which does justice to the problem of involuntariness. See LAYCOCK, supra, at 385 (discussing replevin and ejectment). But it remains instructive that where damages are the remedy, perhaps because the stolen property has been lost, the court does not require that the thief pay the victim an above-cost price that would provide the victim with an economic profit, but only a price equal to the cost of the property.

Such at-cost compensation is an element of domestication - of slavery-but only one element. For at-cost compensation to rise to such the thief must dispossess the victim of all of the victim's property, including freedom of movement, eliminating the victim's life alternatives and in so doing shrinking down the economic cost of the stolen property to the bare requirements of subsistence. Subsistence is the opportunity cost of everything for a person for whom the only alternative is death. See supra Section V.B.2.

${ }^{230}$ See FOSTER \& FOSTER, supra note 209, at 8-16.

${ }^{231}$ See DeLong, supra note 154, at 11; MANNING, supra note 209, at 175.

${ }^{232}$ See R. H. Coase, The Nature of the Firm, 4 EconOMICA 386, 396-97 (1937) (discussing factors that limit firm size); R. Preston McAfee \& John McMillan, Organizational Diseconomies of Scale, 4 Journal of Economics \& MANAGEMENT STRATEGY 399, 3 (1995) (arguing that the information costs of hierarchical supervision limit firm size). 
had a population less than half the size of the workforce of Cargill, a leading agribusiness today. ${ }^{233}$ And Ur shared Cargill's focus on farming. ${ }^{234}$ In Ur's accountants and quotas one senses the internal planning undertaken by a modern business seeking to allocate employees and resources to meet projected demand. ${ }^{235}$ Civilization had not yet reached the minimum efficient scale of the firm, let alone an upper bound on efficient size, and so the king could dictate the terms of trade between his subjects and himself with relative efficiency. ${ }^{236}$ The economy was small enough that the general equilibrium problem could still be solved with brute force. ${ }^{237}$

But even then there was a problem: the kings who ran the civilizations operated them for their own benefit, not that of the public. ${ }^{238}$ The only consumers, in the sense of those able to dictate their preferences to the market, were the ruler and a small nobility. ${ }^{239}$ The public at large had little say in how they worked or what they consumed, and indeed their servile status meant that they had no power to impose their preferences on anyone, even if it were considered acceptable for them to try to do so. ${ }^{240}$ But all parties to contemporary debates, particularly Chicago, believe in the doctrine of consumer sovereignty, which holds that consumers should in general have

\footnotetext{
233 See Tertius Chandler, Four ThOUSAND YeARs OF URBAN Growth: AN Historical Census (Edwin Mellen Pr Revised edition ed. Nov. 1987); Tony Sekulich, Top Ten Agribusiness Companies in the World, Tharawat MAGAZINE (Feb. 7, 2019), https://www.tharawat-magazine.com/facts/top-ten-agribusiness-companies/.

${ }^{234}$ See FOSTER \& FOSTER, supra note 209, at 67-68; Sekulich, supra note 233.

235 See Alfred D. Chandler JR, ScAle AND SCOPE: THE DYNAMICS OF Industrial CAPITALISM 31-34 (The Belknap Press Mar. 1994).

${ }^{236}$ See SCHERER \& ROSS, supra note 49, at 103 (defining minimum efficient scale); McAfee $\&$ McMillan, supra note 232, at 3 (discussing efficiency limits on firm size).

${ }^{237}$ For general equilibrium, see supra Section V.A.1.

238 This is nicely illustrated by the title that Sneferu, the first Fourth Dynasty king of Ancient Egypt, took for himself: neb, which means 'not just 'lord,' but 'possessor,' 'owner,' and 'keeper."' See WILKINSON, supra note 227, at 58. Toby Wilkinson also observes that while the Egyptian populace may have benefited indirectly from enhancements to the nation's political and economic infrastructure, it is difficult not to see the enhancements as essentially self-serving on the part of the ruling elite. In ancient Egypt an increase in national prosperity facilitated the construction of yet more sumptuous monuments celebrating the king - not the provision of facilities for the masses or the amelioration of their living conditions.
}

See id. at 46.

239 See WILKINSON, supra note 227, at 46-47 (discussing the Ancient Egyptian nobility as beneficiaries of the civilization's economic system).

${ }^{240}$ See id. at 46, 59 (observing that economic progress benefitted only the elite and that the absence of accounts of state repression likely reflect the absolute power of the state and the "unthinkable" nature of opposition to it). 
the power to dictate what the economy produces. ${ }^{241}$ Even modern attempts at central planning attempted to do justice to this principle. ${ }^{242}$ The Soviet planners did not strive to make the economy produce exclusively for the delight of the politburo, but rather sought distribute the surplus generated by production more broadly. ${ }^{243}$ It follows that while one might be able to speak of the centrally planned economies of the premodern world as occasionally efficient in the sense that some may have been so small that the ruler could organize them efficiently to produce everything that the ruler wanted, they were not effective economies in the modern sense of being efficient at translating the public's preferences into economic output. ${ }^{244}$ By contrast, the modern firm is not organized to produce only what the CEO personally wishes to consume, but is instead disciplined by the market, forced to direct the firm's employees to produce what consumers desire, making it effective in a way that the centrally planned economy is not. ${ }^{245}$

Economic organization in the premodern age was not of course always as planned as it was in Third Dynasty Ur. The level of planning varied greatly from place to place and over time but the view that the productive activities of the realm should be planned whenever possible was a constant, even if the sovereign sometimes lacked the power fully to impose his will upon his subjects, forcing him to acquiesce in property rights for some of them. ${ }^{246}$

${ }^{241}$ See Averitt \& Lande, supra note 180, at 715-16; Lerner, supra note 180, at 258; Joseph Persky, Retrospectives: Consumer Sovereignty, 7 JOURNAL OF ECONOMIC PERSPECTIVES 183, 183 (Mar. 1993) ("Classical economics has long asserted the primacy of consumption, a claim that can be traced back at least to Adam Smith[.]"); Stefan Schwarzkopf, The Political Theology of Consumer Sovereignty: Towards an Ontology of Consumer Society, 28 THEORY, CUlTURE \& SOCIETY 106, 117-19 (SAGE Publications Ltd May 2011).

242 See Arthur Cecil Pigou, Socialism versus Capitalism 8 (Macmillan and Co., Limited 1949) ("[W]e can imagine a small aristocratic group at the head of a community of slaves, planning the industry of a country exclusively in its own interest without any regard for that of the slaves. Nobody would call this socialism.").

${ }^{243}$ See KornaI, The Socialist System: The Political ECONOMY OF COMMUNiSM 311-23 (Princeton University Press 1992).

${ }^{244}$ See Lerner, supra note 180, at 258-59. They could have been pareto efficient economies, so long as one assumes that the initial endowment of the public was very low, and hence that production made the king very much better off without making anyone else worse off. See VARIAN, supra note 100, at 17. But that kind of efficiency is not the efficient that is expected of a modern economic, which should lift all boats, at least to some extent.

245 See SCHUMPETER, supra note 178, at 85 (discussing the pervasive competitive pressure faced by modern firms).

246 See MANNING, supra note 209, at 229 ("Totally free, 'self-regulating' markets . . never existed in the premodern world. Instead they operated within both state structures and social custom.”); ROBERT S. DUPLESSIS, TRANSITIONS TO CAPITALISM IN EARLY MODERN EUROPE 15-16 (Cambridge University Press Sep. 1997) (describing medieval European peasants as everywhere owing rents to lords but also having "effective possession" of their land and sufficient "autonomy" to dicker with the lord and sometimes "defy[] seigniorial demands" 
Only in the $19^{\text {th }}$ century, when a taste for technological innovation and individual rights started to spread, for reasons that are external to this story, did this fundamental thrust of economic organization toward planning end. ${ }^{247}$ Economies quickly became too large for any one planner to handle, even if the goal was to satisfy only the sovereign. ${ }^{248}$ And with the rise of the notion

due in part to labor shortages); MOKYR, supra note 156, at 396-97 ("What is not in dispute is that eighteenth-century Britain was . . No laissez-faire economy. It was heavily taxed and regulated . . . . It imposed encumbrances on businesses, first and foremost the various restrictions on the formation of joint-stock companies, and the usury laws which limited interest rates charged to a legal maximum. Parliament needed to give its consent to the formation of any kind of business organization such as canals that required a large outlay of capital. Labor markets were still subject to the ancient Statute of Apprentices and Artificers dating back to 1562, which constrained workers in many occupations to a formal apprenticeship before they could be employed in their trade".).

247 See DAVID J. Gerber, LAW AND COMPETITION IN TWENTIETH CENTURY EUROPE: Protecting Prometheus 17-18 (Clarendon Press 2010) ("The French Revolution ushered in by European century in which [the idea of protecting freedom] acquired for many an almost religious time mention. It became a powerful talisman that spawned reverence and provided justifications for a wide range of claims. .. . Liberalism was the political, social, and intellectual 'movement' that surrounded this talisman and made freedom and law the core of its credo. . . . Just as liberals sought to free political conduct from the discretion of absolutist rulers, they also sought to free economic conduct from the constraints imposed under those regimes."); MOKYR, supra note 156, at 10, 399-400 ("The essence of the Enlightenment's impact on the economy was the drive to expand the accumulation of useful knowledge and direct it toward practical use."); Jean-Pierre Hirsch, Revolutionary France, Cradle of Free Enterprise, 94 THE AMERICAN HISTORICAL REVIEW 1281, 1281 ([Oxford University Press, American Historical Association] 1989) ("[Revolutionary] France was probably the first country where 'laissez-faire' was officially accepted by the state and integrated into the new rhetoric of commerce and industry.").

248 See MOKYR, supra note 156, at 397 ("As the economy became more sophisticated and markets more complex, the ability of the government to regulate . . effectively vanished."). This is perhaps best illustrated by the rise of general incorporation in the United States in the $19^{\text {th }}$ century. One might have expected the United States, founded on Enlightenment principles, to have pursued a policy of laissez faire from its inception. Instead, the country followed the European practice of granting corporate charters on a case-by-case basis by act of the legislature, effectively putting the legislature in the position of picking the management of, and planning entry and exit with respect to, all capital-intensive industries. See Ronald E. Seavoy, Laws to Encourage Manufacturing: New York Policy and the 1811 General Incorporation Statute, 46 THE BusinESS HISTORY REVIEW 85, 86-89 ([President and Fellows of Harvard College, Cambridge University Press] 1972); HoRWITZ, supra note 88, at 134 (discussing the transformation of "public service corporations" established by the state for specific purposes "were transformed into private, profit-making organizations"). (Enlightenment effects were seen instead in the way democratically-elected legislatures tended to wield the planning power with greater concern for the public interest. See Seavoy, supra, at $85-86$.) But by the middle of the $19^{\text {th }}$ century state legislatures recognized that their chartering activities, so far from promoting economic growth, had become a bottleneck, so quickly were new industrial opportunities proliferating. See id. at 89-90. They responded by creating "general incorporation laws" that eventually permitted anyone to obtain a corporate 
of individual rights, economies now had to produce for the public, adding millions of consumer preference conditions to the mix and converting the planning problem into the massive and intractable general equilibrium problem described in Section V.A.1. ${ }^{249}$

The result was the proliferation of private firms, which represented a decentralization of planning, and a return to the model of distributed learning in which the economy is peopled by numerous economic agents each trying to learn the quickest route to success. ${ }^{250}$ But unlike the distributed learning that is evolution - the laissez faire of the world of hunter-gatherers - now the learner had a new attribute, that of private property guaranteed by the state. ${ }^{251}$ This new regime of economic liberalism - the regime Chicago defendseffectively maintained the restriction on theft pioneered by premodern central planners, but jettisoned the other parts of planning. ${ }^{252}$ That improved upon evolution, by cutting out the wasteful route to success through predation and forcing firms to produce and trade to get ahead. ${ }^{253}$ But, as will become clear shortly, the prohibition created other problems that antitrust can fix. ${ }^{254}$

There were repeated attempts to bring planning into the modern age and to square it with the demand for individual rights that emerged coincident

charter to engage in any lawful business, without need for express legislative approval. See id. at 89-95 (discussing the experience in New York State in particular); DAVID A Moss, When All Else FAIls: Government AS THE Ultimate RISK MANAGER 68-69 (Harvard University Press 2004) (discussing the transition to general incorporation laws throughout the United States in the 19th century).

${ }^{249}$ See MOKYR, supra note 156, at 399-400 ("The role of the government, it was felt, was to do for the citizens what they could not do for themselves, for whatever reason, but to eschew redistribution as much as possible.").

${ }^{250}$ See HORWITZ, supra note 88, at 134; Seavoy, supra note 248, at 89-95.

${ }^{251}$ The argument is not that the legal institution of property sprang into existence for the first time in the $19^{\text {th }}$ century. Property, recall from the beginning of this Section, is an essential attribute of planned economic systems as well, and so it is not surprising to find that property is an ancient legal concept. See, e.g., Emmanouil M. L. Economou \& Nicholas C. Kyriazis, The Emergence and the Evolution of Property Rights in Ancient Greece, 13 JOURNAL OF INSTITUTIONAL ECONOMICS 53 (Cambridge University Press Mar. 2017). The argument here is that, when planning melted away, property remained and indeed was strengthened. See MOKYR, supra note 156, at 399-403 (discussing the role of property rights in British industrialization).

252 See Angus Burgin, The Great Persuasion: Reinventing FreE MARKets Since the DEPRESSION 176-78 (Harvard University Press Oct. 2012) ("[Milton] Friedman . . thought he 'was going back to some fundamentals rather than creating anything new'; to him, the word 'liberalism' was inadequate only because of the loss of the meaning it had once held.") (internal quotation marks omitted).

253 See supra Section V.B.1.

${ }^{254}$ See infra Part V.C. 
with industrialization. ${ }^{255}$ But these attempts all came to tears. ${ }^{256}$ Liberalism proved superior, in the sense that it proved more conducive to economic growth. ${ }^{257}$ That does not mean, however, that liberalism magically solves the general equilibrium problem any better than does central planning. ${ }^{258}$ It means only that, unlike planning, liberalism does not try to solve an intractable mathematical problem at all, but instead is tolerant of learning at the level of individual economic agents, and indeed channels learning in beneficial directions. ${ }^{259}$

It is worth noting that in addition to property rights, economic liberalism imposes two other restrictions on evolution. Markets force firms to produce what consumer desire only if consumers actually want to impose their preferences on firms, by buying what makes them happiest, and firms want to satisfy those preferences, by seeking to produce what is most profitable. ${ }^{260}$ It is difficult to appreciate today, particularly against the backdrop of the pervasive assumption in economics that individuals pursue only their own self interest, that modern firms must work hard to convince consumers to buy at all, even when buying would make them happier, and that policymakers must work hard to convince firms to seek to maximize profits. ${ }^{261}$ Nature evolved human beings to hanker for food. But it did not evolve them to act always to express themselves through their purchase decisions-always to comb the Internet, looking for the latest and best in consumer products-and it will not do that, because that is unlikely to influence reproductive outcomes, and evolution optimizes only traits that enhance reproductive chances. $^{262}$ So the inducement to learn was greatly reduced, relative to the world of hunting and gathering, with the coming of civilization and the relative plenty it created. ${ }^{263}$ Early trade theorists wrote despairingly of the

\footnotetext{
255 See KORNAI, supra note 243, at 4-11, 110-14 (listing socialist countries and discussing planning); EDEN MEDINA, CYBERNETIC REVOLUTIONARIES TECHNOLOGY AND POLITICS IN ALLENDE'S CHILE 6-7 (2014).

${ }^{256}$ See Peter Murrell \& Mancur Olson, The Devolution of Centrally Planned Economies, 15 Journal of COMPARATIVE ECONOMICS 239, 250-52 (Jun. 1991); John R. Moroney \& C. A. K. Lovell, The Relative Efficiencies of Market and Planned Economies, 63 SOUTHERN ECONOMIC JOURNAL 1084, 1090-91 (Southern Economic Association 1997).

257 See Murrell \& Olson, supra note 256, at 250-52; Moroney \& Lovell, supra note 256, at 1090-91.

258 See supra Section V.A.1.

${ }^{259}$ See supra Sections V.A.1, V.A.2.

${ }^{260}$ Cf. MAS-COLELL ET AL., supra note 101, at 546-50 (incorporating this insight into general equilibrium theory by assuming that economic agents are profit and utility maximizers).

261 See Robert H Frank, Passions Within Reason: The Strategic Role of the EMOTIONS 21-23 (Norton 1988) (discussing the assumption of self interest).

${ }^{262}$ See Domingos, supra note 60, at 122-28 (discussing the "Darwin algorithm").

${ }^{263}$ It is perhaps fanciful to suppose that this accounts for the $10 \%$ reduction in human brain
} 
difficulties of inducing consumers to buy their countries' manufactures, and an entire industry - marketing - arose in industrializing countries to find ways to induce consumers to spend. ${ }^{264}$ Despite the claims of many writers in the liberal tradition that profit maximization is human nature, liberalism has struggled with equal effort to induce firms to seek to maximize profits, going so far as to write the profit maximization requirement into the duty of care in corporate law. ${ }^{265}$ These essentially cultural characteristics, a striving to maximize happiness through purchase decisions, and to maximize profits, are key to the market learner because they ensure that economic agents strive to learn to optimize resource allocations. ${ }^{266}$

\section{The Unfinished Algorithm}

The Chicago School sometimes suggests that there is a difference in kind between regulated markets, such as those subject to antitrust rules, and free markets, understood to consist of laissez faire plus property rights. ${ }^{267}$ But in fact each is merely a different kind of regulation of that preexisting thing called markets, each an attempt to make of markets a better master algorithm. ${ }^{268}$ In savaging antitrust and other forms of government regulation with skepticism, but choosing not to express skepticism about property rights as a mode of achieving efficient allocations of resources, the Chicago School promotes its own preferred approach to regulation-to the master

size over the past 30,000 years. See Maciej Henneberg, Evolution of the Human Brain: Is Bigger Better?, 25 CLINICAL AND EXPERIMENTAL PHARMACOLOGY AND PHYSIOLOGY 745, 745 (1998). (And fanciful as well to suppose that the mental effort required to break the hunter-gatherer mold may represent the enduring pinnacle of human intellectual achievement.)

${ }^{264}$ See THE History OF ECONOMiC Thought: A ReAder (Steven G. Medema \& Warren J. Samuels eds., Routledge Feb. 2004); JAMES D. NORRIS, ADVERTISING AND THE TRANSFORMATION OF AMERICAN SOCIETY, 1865-1920 (Greenwood Press 1990) (describing the role played by advertising in creating a national market for consumer goods in the United States); MOKYR, supra note 156, at 143-44 (discussing the role of fashion in inducing demand in industrializing Britain).

265 See Mark J. Roe, The Shareholder Wealth Maximization Norm and Industrial Organization, 149 U. PA. L. REV. 2063, 2065-66 (2001) (observing that corporate law requires the maximization of shareholder wealth and that in turn implies the maximization of firm profits); Ramsi A. Woodcock, The Antitrust Case for Consumer Primacy in Corporate Governance, 10 UC IRVINE L. REV. 1426-33 (2020).

${ }^{266} C f$. Penrose, supra note 145, at 809-16 (arguing that natural selection alone cannot explain the profit-maximizing behavior of economic agents, which must be attributable instead to internal motivation).

${ }^{267}$ See John S. McGee, Why Not “Deregulation” for Antitrust?, 46 ANTITRUST L.J. 777, 777 (1977).

268 See supra Section V.A.2. 
algorithm - namely, that the algorithm should alone incorporate property rights, along with legal rules requiring that firms maximize profits and an ideology that encourages individuals to act to maximize their own happiness. ${ }^{269}$ The Chicago School is not expressing skepticism about all regulation. For property rights are regulation. ${ }^{270}$

The question posed by Chicago as whether to regulate is really the question whether the machine learning algorithm that is markets-plusproperty-rights can be improved, and if so how. From this perspective, the Chicago School's critique of regulation, understood by Chicago to mean any sort of government intervention beyond the guarantee of property rights, appears no longer to sound in the key of a defense of the natural against the frail and manmade, but rather to sound in that of fear of progress. ${ }^{271}$ Machine learning exploits the gains to be had from constant improvement of imperfect optimization programs. ${ }^{272}$ The notion that the learning algorithm itself cannot be improved appears, against this backdrop, to be arbitrary at best. ${ }^{273}$ Indeed, the history of economic liberalism has itself been a history of constant modification of the learning algorithm in ways that have been so successful that they are taken for granted today, including by the Chicago School. ${ }^{274}$

Consider, for example, the Federal Reserve's rule taxing the issuance of bank notes, which effectively establishes the U.S. dollar as the only currency used for transactions in the United States and eliminates the exchange rate risk that characterizes the use of currencies issued by private banks. ${ }^{275}$ The demise of the bank note has meant that a merchant does not need to worry that acceptance of notes issued by one bank might be riskier than acceptance of notes issued by another bank because the gold backing the notes issued by the first bank might be less secure. ${ }^{276}$ Like the institution of property rights, the institution of the national currency reduces the amounts that producers are required to spend on security by having the government provide security

\footnotetext{
269 See Frank H. Easterbrook, Workable Antitrust Policy, 84 MicH. L. REV. 1696, 1700 (1986) ("The Chicago School is based on skepticism[.]"). For more on Chicago's skeptical arguments, see supra Part IV.

270 This point differs from the argument of progressives that government creates property. Government does not create property, in the sense of dominion and control over a thing. But government does create property rights. See supra Section V.B.1.

${ }^{271}$ For Chicago's dislike of regulation, see BURGIN, supra note 252, at 176-78.

272 See DomingOS, supra note 60, at 6-10.

${ }^{273}$ Indeed, the question what the best possible learning algorithm might be remains an active area of research in the field of artificial intelligence. See id. at 263-64.

274 See Moss, supra note 248, at 53-151 (showing how the institutions of limited liability for corporations, a national currency, and bankruptcy for debtors have all made markets more efficient).

${ }^{275}$ See id. at 87-92, 115 .

${ }^{276}$ See id. at 87-92.
} 
to everyone. In the case of property rights, centralizing the security function in the government means giving the government a monopoly on violence. ${ }^{277}$ In the case of the national currency, centralization means diversification. ${ }^{278}$ Instead of effectively betting on a single bank's investment portfolio by holding that bank's notes, a merchant now bets on the investment portfolio of every bank that borrows from the federal reserve banks, as well as the federal government itself, which backs the federal reserve banks. ${ }^{279}$ Many more borrowers would need to default before the national currency, as opposed to private bank notes, would lose value. And like the property system, the national currency improves the market learning algorithm by making the signaling function of markets more reliable, ensuring that economic agents have a greater incentive to learn value-enhancing conduct. ${ }^{280}$ No longer can a producer that has beaten out the competition and satisfied consumers' preferences discover that the bank notes paid to the producer as a reward are worthless because the banks that issued those notes invested the gold backing the notes unwisely, forcing the producer to go out of business despite having responded properly to consumer signals. ${ }^{281}$

Virtually everything in the law that scholars of law and economics have been able to explain in efficiency terms may be understood to represent a modification of the learning algorithm to improve the algorithm's success relative to the basic markets-plus-property-rights approach. ${ }^{282}$ The bankruptcy laws, the institution of limited liability for corporations, products liability doctrines that shift risk of harm to producers, environmental regulations that force firms to internalize harms inflicted by their productive activities that normally would be borne by others, and many other areas of law, all also represent improvements upon the basic algorithm of economic liberalism. ${ }^{283}$

The antitrust laws are another such tweak. ${ }^{284}$ In order for firms that best satisfy the preferences of consumers to be rewarded by consumers, their productive efforts must be free of harmful interference from other companies. If another company can beat the competition by degrading the quality of competitors' products, or, what amounts to the same thing, by increasing

\footnotetext{
277 See COOTER \& ULEN, supra note 71, at 77-78.

278 See Moss, supra note 248, at 115 (observing that federal government backing had a "risk spreading" effect).

${ }^{279}$ See id. at 115-16.

${ }^{280}$ For this function in the property system, see supra Section V.B.1.

281 See Moss, supra note 248, at 90.

282 See generally POSNER, supra note 181 (attempting to explain the law in terms of efficiency).

${ }^{283}$ See Moss, supra note 248, at 53-85, 123-51, 216-92.

${ }^{284}$ See 15 U.S.C. $§ 1$ et seq.
} 
competitors' costs of production and thereby forcing them to charge higher prices for their products, then that company will survive in the market by making it harder, not easier, for consumers to obtain what they want. ${ }^{285}$ Consumers will purchase the firm's products because they are the best of a diminished field, not because the products are the best possible. ${ }^{286}$ The fact that rewards then flow to the wrongdoers creates an incentive for firms to invest in degrading competing products, rather than in improving their own products, and the economy is then pulled away from the allocation of resources to their most productive uses. ${ }^{287}$

Product-degrading conduct prevents consumers from rewarding the firms that best serve them, as does an absence of property rights. ${ }^{288}$ But the two dysfunctions are distinct. The firm that degrades competitors' products does not take away those products, or even the competitors' facilities or tools, as the firm might do in the absence of property rights. A taking away of a competitor's products may be considered a degradation of the competitor's products, of course, because taking a competitor's products prevents the competitor from selling its own products, effectively degrading the quality of what the competitor has to offer down to zero. Moreover, a taking away of a competitor's tools either prevents the competitor from offering the product, or reduces the product's quality, which obviously counts as degradation of the competitor's products as well. But that is not the sort of degradation that concerns the antitrust laws. Instead, the antitrust laws are interested in degradation caused not by the taking of property but by another means: the denial to competitors of inputs not owned by competitors but which competitors need to acquire to improve their products and which the perpetrator does not need to improve the perpetrator's own products. ${ }^{289}$ That is, the product degradation that the antitrust laws seek to prevent results from the exercise, by the offender, of the offender's own legitimately-acquired property rights over inputs, rather than the violation by the offender of property rights belonging to others. ${ }^{290}$

\footnotetext{
285 See Ramsi A. Woodcock, The Obsolescence of Advertising in the Information Age, 127 YALE L.J. 2270, 2308-14 (2018); Ramsi A. Woodcock, Digital Monopoly without Regret, CONCURRENCES, 2020, at 53.

${ }^{286}$ See Woodcock, The Obsolescence of Advertising in the Information Age, supra note 285, at $2308-14$.

${ }^{287}$ See id.

${ }^{288}$ See id. (discussing product-degrading conduct); POSNER, supra note 221, at 30.

289 See Woodcock, The Obsolescence of Advertising in the Information Age, supra note 285, at 2308-14; Woodcock, Digital Monopoly without Regret, supra note 285.

${ }^{290}$ See Woodcock, The Obsolescence of Advertising in the Information Age, supra note 285, at 2308-14. The antitrust laws would of course not be needed if they were merely to prohibit violations of property law.
} 
The irony of Chicago School claims that the antitrust laws do collateral damage to the economy is that the antitrust laws in fact seek to mitigate collateral damage done to the economy by a different legal regime, one that is much prized by the Chicago School: that of property. ${ }^{291}$ For in allowing producers to lock down their property against theft, property rights at once ensure that firms can secure rewards for their productive activities, which improves the algorithm, and enables firms to deny superior firms - firms that can better serve consumers than can they-access to the inputs they require to serve consumers, which reduces the effectiveness of the algorithm. ${ }^{292}$ The antitrust laws modify the algorithm to take this particular edge off of property rights. ${ }^{293}$ Indeed, as restrictions on the ability of owners to deny inputs when doing so degrades competitors' products, the antitrust laws may be reconceptualized as extended rules of property law themselves, redefining the limits of the owner's property rights to enables competitors to take the owners' inputs under certain circumstances. ${ }^{294}$

The key problem faced by antitrust in carrying out this tweak, one that is the ultimate source of Chicago School skepticism, is how to determine when a denial of inputs actually disrupts the consumer-preference-signaling process at the heart of the algorithm. ${ }^{295}$ For firms that succeed by producing products that consumers want also necessarily deny inputs to competitors: those inputs that the successful firms themselves use to produce their superior products. $^{296}$ That denial may be said to degrade competitors' products in the sense that competitors' products would be better were the inputs to be supplied. ${ }^{297}$ But stopping such denials would be bad for the algorithm.

\footnotetext{
${ }^{291}$ For the Chicago School's suggestion that the antitrust laws pollute the economy, see supra Section IV.

${ }^{292}$ See Woodcock, The Obsolescence of Advertising in the Information Age, supra note 285, at 2308-14. This problem of excessive property protection preventing healthy competition has been most clearly discussed in the intellectual property context in recent years. See Denicolò, supra note 7, at 689 (deriving an expression for the optimal "length" and "breadth" of patent rights); Ramsi A. Woodcock, Inconsistency in Antitrust, 68 U. MIAMI L. REV. 105, 126-35 (2013) (showing how excessive intellectual property protection can harm consumers).

${ }^{293}$ See Woodcock, The Obsolescence of Advertising in the Information Age, supra note 285, at 2308-14.

${ }^{294}$ See Woodcock, supra note 292, at 166-67 ("We can think of law, including property law, as part of a system of input control. Antitrust corrects a perversity in this system according to which, contrary to the normal effect and intent of input control, it tends to reduce production instead of to increase it.").

295 See Easterbrook, supra note 50, at 5 ("[Judicial w]isdom lags far behind the market.").

${ }^{296}$ See Woodcock, The Obsolescence of Advertising in the Information Age, supra note 285, at 2308-14; Woodcock, Digital Monopoly without Regret, supra note 285, at 54-55.

${ }^{297}$ See Woodcock, The Obsolescence of Advertising in the Information Age, supra note 285, at 2308-14.
} 
Indeed, it would have the same effect as theft, because it would force the creator of the superior product to share the means to produce the product, and thereby reduce or eliminate the rewards for success. ${ }^{298}$ The question that antitrust enforcers face is the question whether a denial of inputs is incident to activity that does not improve the denier's product but only degrades the quality of competitors' products. ${ }^{299}$

The substantive heart of Chicago School skepticism is not really that regulation as such is harmful-for in supporting property rights Chicago Schoolers support a form of regulation-but rather skepticism about the ability of antitrust enforcers to distinguish product degrading input denials from product-improving input denials. ${ }^{300}$ The Chicago School position is really that the algorithm works best when only property rights are protected, because the code preventing product degradation is faulty, and results in a harmful weakening of property rights in the form of forced sharing of property that firms are already putting to their most productive uses. ${ }^{301}$ From the Chicago School perspective, antitrust in practice reduces the effectiveness of the algorithm, however well-intentioned antitrust might be. ${ }^{302}$ That is the entire substance of the Chicago School's error cost skepticism: the notion that antitrust is unable to distinguish good from bad conduct. ${ }^{303}$

Now, properly framed by the metaphor of the market as algorithm, the arbitrary character of Chicago School skepticism becomes clear. Because we can bring the same skepticism to bear on the system of property rights itself. We can wonder how much product-improving activity in the workplace is

\footnotetext{
${ }^{298}$ See id.

${ }^{299}$ See id.

300 See Easterbrook, supra note 50, at 5 ("Why do particular practices work? The firms that selected the practices may or may not know what is special about them. They can describe what they do, but the why is more difficult. Only someone with a very detailed knowledge of the market process, as well as the time and data needed for evaluation, would be able to answer that question. Sometimes no one can answer it.").

301 See id. at 39-40 ("Antitrust is an imperfect tool for the regulation of competition. Imperfect because we rarely know the right amount of competition there should be, because neither judges nor juries are particularly good at handling complex economic arguments, and because many plaintiffs are interested in restraining rather than promoting competition. . . . Something must be done. That 'something' is to replace the existing method of antitrust analysis with a series of simple filters. . . . Each filter errs, if at all, on the side of permitting questionable practices."); Verizon Commc'ns Inc. v. Law Offices of Curtis V. Trinko, 540 U.S. 398, 407-8 (U.S. 2004) ("Compelling . . . firms to share the source of their advantage is in some tension with the underlying purpose of antitrust law, since it may lessen the incentive for the monopolist, the rival, or both to invest in those economically beneficial facilities.").

${ }^{302}$ See Easterbrook, supra note 50, at 39-40.

${ }^{303}$ See Manne \& Wright, supra note 56, at 165-66 (describing an antitrust "bias toward Type 1 error," meaning false findings of liability).
} 
discouraged by the fact that employers own the inventions that employees generate during business hours. ${ }^{304}$ Property law would do a much better job of rewarding productive activity were the law to be applied more carefully to ensure that each person controls the fruits of his own labor. ${ }^{305}$ Moreover, we can view property rights as exacerbating the problem of input denial that antitrust seeks to solve, in effect creating a new problem even as it solves the problem of physical security. Absent property law, a firm might have more difficulty using input denial to degrade competitors' products because productive firms would be free to steal the inputs they need. ${ }^{306}$ The Chicago School's skepticism regarding the efficacy of antitrust, bereft as it is of attendant skepticism regarding the efficiency of property rights, is revealed to be a directed skepticism, wielded as a sword in defense of the view that property rights are the only helpful approach to the algorithm. ${ }^{307}$

But all this is not to say that the mid-century antitrust regime had no room itself for improvement, or that Chicago-School critiques led to no improvement. ${ }^{308}$ In the middle of the $20^{\text {th }}$ century, antitrust did not distinguish between product-degrading input denials and product-improving input denials, but instead prohibited both to the end of promoting competition and deconcentration for their own sakes. ${ }^{309}$ That meant treating input denial as violative of the antitrust laws even when it was a denial of inputs used by the firm to improve its own products, meaning a refusal to share the fruits of productive labors, rather than an attempt to degrade the products of others. ${ }^{310}$ This was a mistake, and it did hurt the algorithm, although whether it did more bad than good is not clear. Probably the most famous example of this

\footnotetext{
304 See MERGES ET AL., supra note 229, at 84-89.

305 See PoSNER, supra note 221, at 30; cf. Easterbrook, supra note 269, at 1702 ("Antitrust is regulation. Regulation ought not rest on hope that judges will solve complex problems."). 306 See Woodcock, supra note 181, at 554-55.

307 Cf. KENNEDY, A CRITIQUE OF AdJUDICATION, supra note 9, at 180-83 (discussing "strategic behavior" in adjudication).

${ }^{308}$ See F. M Scherer, Conservative Economics and Antitrust: A Variety of Influences, in How THE ChICAGo School OVERShOt THE MARK: THE EFFECT OF CONSERVATIVE ECONOMIC ANALYSIS ON U.S. ANTITRUST 30 (Robert Pitofsky ed., 2008) (discussing the importance of Chicago School contributions).

309 See N. Pac. Ry. Co. v. United States, 356 U.S. 1, 4 (Supreme Court 1958) ("The Sherman Act was designed to be a comprehensive charter of economic liberty aimed at preserving free and unfettered competition as the rule of trade. It rests on the premise that the unrestrained interaction of competitive forces will yield the best allocation of our economic resources, the lowest prices, the highest quality and the greatest material progress, while at the same time providing an environment conducive to the preservation of our democratic political and social institutions. But even were that premise open to question, the policy unequivocally laid down by the Act is competition.").

310 See Dennis W. Carlton, A General Analysis of Exclusionary Conduct and Refusal to Deal-Why Aspen and Kodak Are Misguided, 68 ANTITRUST L.J. 659, 672-83 (2001).
} 
mid-century mistake is the court's decision to condemn Alcoa for increasing the supply of aluminum to meet demand. ${ }^{311}$ The Court correctly apprehended that in expanding supply to meet demand, Alcoa was denying competitors access to the essential inputs that are customers. ${ }^{312}$ The result was that too few customers remained available to make entry by competitors into the market profitable. ${ }^{313}$ Competition was therefore harmed. ${ }^{314}$ But consumers did not suffer as a result. ${ }^{315}$ To the contrary, consumers gained access to supply without delay. ${ }^{316}$ Alcoa's refusal to share customers with competitors allowed Alcoa to provide customers with a better, more timely, product. $^{317}$ The Court's willingness to sanction Alcoa for doing that reduced the effectiveness of the algorithm. ${ }^{318}$ And also, along with other decisions of this period, triggered the Chicago School's attacks on antitrust. ${ }^{319}$

While the Chicago School was right to attack the Alcoa decision, and others like it, skepticism was the wrong tool. The problem presented by Alcoa and other mid-century cases was not that antitrust enforcers did not know how to distinguish between product-improving and product-degrading conduct, but that enforcers did not wish to distinguish between the two because at the time they sought competition for its own sake. ${ }^{320}$ So skepticism regarding the ability of antitrust to improve the algorithm was not warranted. Or was at least overbroad. For as alluded above, one can turn an equally skeptical eye upon all parts of the algorithm, including the regime of property rights. The approach that the Chicago School should have taken would have been to argue that antitrust enforcement should be changed, rather than eliminated on the grounds of inadministrability. ${ }^{321}$ The solution to antitrust's

\footnotetext{
311 See United States v. Aluminum Co. of Am., 148 F. 2d 416, 430-31 (U.S. 1945); GAVIL ET AL., supra note 42, at 488-89.

312 See United States v. Aluminum Co. of Am., 148 F. 2d at 430-31.

${ }^{313}$ See id.

${ }^{314}$ See id.

315 See Herbert Hovenkamp, Federal Antitrust Policy, the Law of Competition AND ITS PRACTICE 378-79 (6th ed. 2020).

316 See id.

${ }^{317}$ See id.

${ }^{318}$ See id.

319 See BORK, supra note 3, at 164-75.

${ }^{320}$ See N. Pac. Ry. Co. v. United States, 356 U.S. 1, 4 (Supreme Court 1958).

${ }^{321}$ See INDUSTRIAL CONCENTRATION, supra note 10, at 231 (quoting Harold Demsetz calling for a repeal of the antitrust laws). To be sure, some Chicago authors, such as Frank Easterbrook and Robert Bork, did not actually go so far as to call for repeal, but the changes to the law that they advocated, particularly in the context of single-firm conduct claims, were tantamount to repeal. Easterbrook advocated the replacement of existing law with a series of presumptions that would err on the "side of permitting questionable practices." See Easterbrook, supra note 50, at 39-40. Bork thought that all single-firm conduct should be treated as legal if there was any "efficiency potential"-something that would seem to exist
} 
use of the wrong algorithm was to change the algorithm, not abandon it entirely.

In the event, Chicago failed to eliminate antitrust, and was instead forced, by an antitrust establishment that resisted repeal, however half-heartedly, to embrace what has proven to be an unworkable compromise. ${ }^{322}$ That compromise was the adoption of the consumer welfare standard, which effectively charges courts with making liability decisions that are consistent with the optimization of resource allocation, and in so doing addresses the Chicago School's concerns about error without putting an end to the antitrust laws, at least on paper. ${ }^{323}$ In practice, the compromise has proven unworkable because courts have not so far been able to reduce the consumer welfare standard to a coherent rule-that is, to an algorithm, rather than an aspiration-with the result that antitrust today looks like a return to the pencil-and-paper approach to allocation employed by the central planners of old. ${ }^{324}$ For now in every case the courts are required to calculate the effects of the challenged conduct on consumer welfare, putting the courts in the position of having to decide whether denial of an input or its provision is optimal on a case-by-case basis. ${ }^{325}$ Court are therefore not asked to learn, by using the new information provided by new cases to tinkering with old rules,

in every case - along with an absence of anticompetitive intent, something that is normally very hard to establish. See BORK, supra note 3, at 346. The skeptical spirit of these positions is quite explicit. Here, for example, is Easterbrook:

This is a profoundly skeptical program - skeptical of simple models, skeptical of simple analysis, skeptical of the ability of courts to make things better even with the best data. Skepticism is why the Workable Antitrust Policy School seems to favor little other than prosecuting plain vanilla cartels and mergers to monopoly. Its adherents are reasonably sure that these two things are harmful to consumers (though there are scattered doubters); these incurable skeptics doubt that other intervention is worth the costs.

Easterbrook, supra note 269, at 1701.

322 See Ramsi A. Woodcock, The Hidden Rules of a Modest Antitrust, 105 MINN. L. REV. (2021).

${ }^{323}$ See Kirkwood \& Lande, supra note 97, at 197-201. Under the consumer welfare standard, courts are required to use the antitrust laws to achieve resource allocations that are optimal from the perspective of maximizing the welfare of consumers, rather than that of maximizing the welfare of society as a whole. See id. However, in practice the two projects often coincide. See Richard Schmalensee, Thoughts on the Chicago Legacy in U.S. Antitrust, in HOW THE Chicago School Overshot the Mark: The EfFect of Conservative Economic ANALYSIS ON U.S. ANTITRUST 11 (Robert Pitofsky ed., Oxford University Press 2008).

${ }^{324}$ See Woodcock, The Hidden Rules of a Modest Antitrust, supra note 322; Maurice E. Stucke, Does the Rule of Reason Violate the Rule of Law?, 42 U.S. DAVIS L. REV. 1375, 1461-66 (2009). For central planning, see supra Sections V.B.3, V.A.1.

${ }^{325}$ See Woodcock, The Hidden Rules of a Modest Antitrust, supra note 322; Stucke, supra note 324. 
but instead are asked to determine the optimal allocation of resources in each case, a task that is impossible as a theoretical matter because the imposition of efficient allocations of resources requires intervention in all markets at the same time, as opposed to the prohibition of conduct in a single antitrust case. ${ }^{326}$ The rules applied by the algorithm are supposed to substitute for the inability of enforcers, economic planners, or anyone else, to solve the optimization problem. ${ }^{327}$ If courts embark on the demonstrably futile project of solving general equilibrium problems, rather than the tractable problem of learning better legal rules, then the market's potential as a learning algorithm

326 For the importance of learning, see supra Section V.A.2. For the impossibility of achieving efficiency through a myopic focus on an individual market, as well as the broader problem of imposing efficient allocations of resources by fiat, judicial or otherwise, see supra Section V.A.1.

The courts in fact understand the importance of learning and profess to learn over time whether to apply a per se rule of illegality to a particular case, and to understand learning as an imperfect process:

Once experience with a particular kind of restraint enables the Court to predict with confidence that the rule of reason will condemn it, it has applied a conclusive presumption that the restraint is unreasonable. As in every rule of general application, the match between the presumed and the actual is imperfect. For the sake of business certainty and litigation efficiency, we have tolerated the invalidation of some agreements that a fullblown inquiry might have proved to be reasonable.

Arizona v. Maricopa County Medical Soc., 457 U.S. 332, 344 (1982).

But the courts do not seem to have understood that they can learn different kinds of per se rules, and not just whether to impose a particular per se rule or not. As a result the courts have not sought to learn better per se rules, and indeed in their embrace of futile case-bycase adjudication under the "rule of reason" moniker the courts have foreclosed to themselves any opportunity to learn. See Woodcock, The Hidden Rules of a Modest Antitrust, supra note 322. In machine learning terms, the rule of reason is an example of extreme "overfitting." See DoMINGOS, supra note 60, at 73. It amounts to a learning algorithm that says: the rule is whatever collection of cases and their associated outcomes that you already know. See id. Extreme overfitting of this kind makes learning impossible because it does not allow for any generalization from past cases. See id.

The defective approach to learning discussed in Section V.A.2, that the length of a diagonal can be calculated according to the rule that the length of the diagonal of a rectangle of base three and height four is five, that of base six and height eight is ten, and that of base 1 and height 1 is the square root of two, is an example of such extreme overfitting. Such a rule works very well for the three cases that make up the rule, but is entirely useless in finding the right answer for new cases. Pose the question what the length of the diagonal for a rectangle of base five and height 12 should be, and the algorithm will draw a blank. The rule of reason would have the courts effectively draw out the rectangle on a piece of paper and use a ruler to find the answer-13 - and then simply add five, 12, and 13 to the existing rule, effectively gaining nothing in terms of predictive power with respect to any further new cases. See id.

${ }^{327}$ See supra Sections V.A.1, V.A.2. 
is wasted. ${ }^{328}$

The ambiguous and unlawlike character of the consumer welfare standard has fed Chicago School skepticism about the usefulness of the antitrust laws. ${ }^{329}$ Frank Easterbrook, for example, once called for ending antitrust enforcement until "doubts" about "the ability of courts to make things better even with the best data . . have been overcome." "330 The proper response is not, however, to end antitrust but to fashion a rule-an addition to the algorithm - that is likely to channel learning toward the outcome of consumer welfare maximization that the courts now rightly seek to achieve. The proper rule is the one I have already described: only to prohibit conduct that degrades products without improving the defendant's own. ${ }^{331}$ Adoption of that rule will advance the consumer welfare project, because the rule ensures that rewards flow to those who serve consumers best. ${ }^{332}$ But the rule is still a rule, an algorithm, rather than a command to achieve optimal outcomes, and so will spare courts the need to act as central planners. ${ }^{333}$

That a prohibition on product-degrading conduct is rule-like-code rather than calculation - is evident from the fact that the prohibition is defined in terms of something that is empirically verifiable but is other than an optimal outcome: whether the conduct improves the quality of the defendant's own product. ${ }^{334}$ Put another way, for liability to attach the rule requires only a showing that the conduct is purely destructive. ${ }^{335}$ While destruction here means a making of competitors' products less desirable to consumers, and the destructiveness of conduct cannot therefore be determined without considering the effects of conduct on consumer welfare, that consideration is much more limited than the economic analysis of welfare effects required today. ${ }^{336}$ All that is required is the exercise of judicial intuition regarding

\footnotetext{
${ }^{328}$ See supra Sections V.A.1, V.A.2.

329 See Easterbrook, supra note 50, at 11-14, 39-40 (rejecting the rule of reason as impracticable and calling for presumptions that err on the side of underenforcement); Peter Nealis, Per Se Legality: A New Standard in Antitrust Adjudication under the Rule of Reason, 61 OHIO ST. L.J. 347, 349 (2000) (arguing that due to the impracticability of the rule of reason all practices currently subject to that rule should be made per se legal).

${ }^{330}$ See Easterbrook, supra note 269, at 1711-12.

${ }^{331}$ See Woodcock, The Obsolescence of Advertising in the Information Age, supra note 285, at 2308-14; Woodcock, Digital Monopoly without Regret, supra note 285, at 54-55.

332 See Woodcock, The Obsolescence of Advertising in the Information Age, supra note 285, at $2308-14$.

${ }^{333}$ Cf. Verizon Commc'ns Inc. v. Law Offices of Curtis V. Trinko, 540 U.S. 398, 408 (U.S. 2004) (observing that it would be inappropriate to ask courts to act as central planners).

${ }^{334}$ See Woodcock, The Obsolescence of Advertising in the Information Age, supra note 285, at $2308-14$.

${ }^{335}$ See id.

${ }^{336}$ See Stucke, supra note 324, at 1461-66 (describing the difficulty of rule of reason analysis
} 
whether, as an engineering matter, any consumer of the defendant's own products could have derived a benefit from the defendant's behavior. ${ }^{337}$ That is no more difficult than what is required to identify property rights today, whether patent rights based upon a showing of nonobviousness, or personal property based on a showing that Pierson was first to catch the fox or spear the whale, or real property rights based upon a showing that the land was improved, either mistakenly or in open and notorious fashion. ${ }^{338}$

There can be little doubt that all forms of government interference with the state of nature, from the institution of property rights to the antitrust laws, involve error. ${ }^{339}$ Property rights are sometimes acquired by people who do not know how to put the property to its most efficient use and who may be unwilling to sell the property at any price, for idiosyncratic reasons. ${ }^{340}$ Similarly, the antitrust laws are sometimes inadvertently used to compel a firm to share property that the firm is using to improve its own products, lessening the rewards to socially valuable business behavior. ${ }^{341}$ And so on. But overall, the algorithmic approach to the allocation of resources has done very well, relative to the centrally-planned approach, and to the state of nature. ${ }^{342}$ Even when the mid-twentieth-century antitrust laws seemed intentionally to be penalizing success, the economy grew, and indeed grew faster than it does today. ${ }^{343}$ Similarly, a generation of weak antitrust carried out under the burdensome rule of reason does not appear to have destroyed the economy, even if the growth slowdown relative to the middle of the $20^{\text {th }}$ century can be attributed entirely to changes in antitrust policy, which seems unlikely. ${ }^{344}$ That is not to say that antitrust is unimportant-a waste of

today).

${ }^{337}$ See Woodcock, The Obsolescence of Advertising in the Information Age, supra note 285, at 2308-14.

338 See MERGES ET AL., supra note 229, at 257-90; DUKEMINIER ET AL., supra note 229, at 18-28, 120-21 (discussing the great cases of Pierson v. Post and Ghen v. Rich, as well as adverse possession); LAYCOCK, supra note 229, at 630-31 (discussing the buy-sell remedy in mistaken-improver cases).

${ }^{339}$ Cf. Easterbrook, supra note 50, at 39 (“Antitrust is an imperfect tool . . ..”).

340 See Brian Angelo Lee, Just Undercompensation: The Idiosyncratic Premium in Eminent Domain, 113 CoLUM. L. REV. 593, 599-601 (Columbia Law Review Association, Inc. 2013) ("Both courts and commentators have observed that at any given time the owner of some specific piece of property may personally place a higher value on that property than the market does.").

${ }^{341}$ See HoVENKAMP, supra note 315, at 381 (discussing the 1927 Kodak case).

342 See supra Section V.B.

343 See Einer Elhauge, Horizontal Shareholding, 129 HARV. L. REV. 1267, 1293 (2016) (discussing the higher growth rate and arguing that antitrust policies of that era were actually responsible for it).

${ }^{344}$ See id. (recounting that economic growth in the United States declined from $2 \%$ per year to $1.3 \%$ per year between the mid- and late-20th century); Baker, supra note 1, at 3-7 
enforcement resources - but only that the costs of getting antitrust wrong do not appear to be all that great. ${ }^{345}$ There is room for experimentation, and if at some point the algorithm is improved thereby, then so much the better. The antitrust laws are not an airplane trying to get off the ground, and therefore do not present a danger of catastrophic mistake, although the antitrust laws are airplane-like in the sense that their effects cannot be modeled in closeform mathematics, and trial and error is therefore an inherent part of the process by which the antitrust laws may be improved. ${ }^{346}$ The antitrust laws are also not a scientific project, in which the field may advance only once a concept is thoroughly understood and all expert dissent has ceased. ${ }^{347}$ Antitrust, like all applied economics, is ultimately a branch of artificial intelligence, writ large, code running on society understood as a computer, and the best code learns.

\section{CONCLUSION}

Life demonstrates the power of the blind groping of evolution to achieve, and the astonishing passage of human societies first into civilization and central planning, and then into industrialization and liberalism, demonstrates the even greater power of intelligently-chosen social algorithms to achieve. But this power cannot be honed or improved unless the law is confident enough always to tinker with the algorithm rather than to treat any particular version of it as inviolate, as the Chicago School would do in suggesting that any version that attempts to improve upon liberalism's basic recipe of property rights must be unworkable. Indeed, economic historians are increasingly concluding that the willingness to tinker, more even than property rights or free markets, is responsible for the Industrial Revolution itself. ${ }^{348}$

If to choose laissez faire in its purest form, absent even the right to property, is to choose biological evolution, and to choose central planning is to choose the glories of the ancient world, then to choose property rightsan economic algorithm that channels the evolutionary process in productive directions - is to choose economic growth. And to choose regulation, and particularly antitrust regulation, is to choose more carefully to channel

\footnotetext{
(cataloguing changes in antitrust over this period).

345 Cf. Elhauge, supra note 343, at 1284-91 (arguing that antitrust policy drives macroeconomic outcomes).

346 See supra Part IV.

${ }^{347}$ See supra Part IV.

${ }^{348}$ See MOKYR, supra note 156, at 9-10 (identifying "the drive to expand the accumlation of useful knowledge and direct it toward practical use" as responsible for the Industrial Revolution).
} 
evolution, and further to increase growth. 